\title{
Current trends on food tourism approaches through a conceptual framework of food tourism management
}

\section{Georgios Angelakis and Christos Lemonakis*}

\author{
Hellenic Mediterranean University, \\ Fournia Lakonia, 72100, \\ Agios Nikolaos, Crete, Greece \\ Email: angelakis@maich.gr \\ Email: lemonakis@hmu.gr \\ *Corresponding author
}

\section{Emilios Galariotis}

Audencia Business School,

8 Route de la Jonelière, B.P. 31222 , 44312 Nantes, Cedex 3, France

Email: egalariotis@audencia.com

\section{Constantin Zopounidis}

Technical University of Crete, Akrotiri Campus, 73100, Chania, Crete, Greece and Audencia Business School, 8 Route de la Jonelière, B.P. 31222 , 44312 Nantes, Cedex 3, France Email: kostas@dpem.tuc.gr

\begin{abstract}
In recent years, food tourism has received increasing preference among tourists and attention from scholars as an alternative and significant form of tourism. At least one-third of the spending of tourist visitors to a destination is used to purchase local food and related food activities. This paper derives current trends in food tourism by identifying food tourism approaches and establishing a theoretical framework for food tourism management by considering both tourists' and stakeholders' perspectives, which could provide a more holistic approach. In addition, the work focuses on tourists' behavioural outcomes, i.e., intentions to purchase/consume, recommend and revisit, depending on whether it is a local food product or a gastronomic industry/destination. The interrelationships of the main factors such as motivations, knowledge, culture, history, authenticity, experiences, values, beliefs, emotions, desires, perceptions, satisfaction and involvement are considered. Implications and future research contributions are also discussed.
\end{abstract}

Keywords: food tourism; management; local food; food service establishments; destination image; behavioural intentions; stakeholders' network. 
Reference to this paper should be made as follows: Angelakis, G., Lemonakis, C., Galariotis, E. and Zopounidis, C. (2022) 'Current trends on food tourism approaches through a conceptual framework of food tourism management', Int. J. Knowledge Management in Tourism and Hospitality, Vol. 2, No. 4, pp.331-365.

Biographical notes: Georgios Angelakis is a $\mathrm{PhD}$ candidate at the Hellenic Mediterranean University, Department of Management Science and Technology (Agios Nikolaos, Crete, Greece). Since 2005, he has been involved in the management and research activities in a large number of EU and national research projects implemented by the Program of Business Economics and Management of the CIHEAM-Mediterranean Agronomic Institute of Chania. His research interests are focused mainly on issues related to tourism marketing and management, food industry, circular economy and sustainable development.

Christos Lemonakis is an Assistant Professor of Business Administration on SMEs Management at the Hellenic Mediterranean University, Department of Management Science and Technology (Agios Nikolaos, Crete, Greece). His current research interests are tourism management, small and medium enterprises management and business organisation and leadership.

Emilios Galariotis is a Professor of Finance and Associate Dean for Research at Audencia Business School (EQUIS, AMBA, AACSB), France. He holds a PhD and an HDR. He sits on the boards of Directors of the Affi, the FEBS and the HAEE. He has published in the European Journal of Operational Research; Journal of Banking and Finance; Journal of Business Ethics, Energy Economics; Energy Journal; Energy Policy; Technological Forecasting and Social Change, Journal of Financial Stability; Journal of Economic Behavior and Organization; Journal of Regulatory Economics; Journal of Business Research, Annals of Operations Research; Small Business Economics; among others.

Constantin Zopounidis is a Professor of Financial Engineering and Operations Research, at TUC (Greece), Distinguished Research Professor in Audencia Business School (France), and Senior Academician of Royal Academy of Doctors and Royal Academy of Economics and Financial Sciences (Spain). He is Editor-in-Chief in International Journal of Multicriteria Decision Making (Inderscience), Operational Research: An International Journal (Springer), International Journal of Financial Engineering and Risk Management (Inderscience) and Associate Editor in International Journal of Banking, Accounting and Finance (Inderscience), International Journal of Data Analysis Techniques and Strategies (Inderscience), and member of the editorial board in the European Journal of Operational Research (Elsevier).

\section{Introduction}

Food tourism is considered an alternative form of tourism compared to mass tourism, attracting highly interested tourists (Douglas et al., 2001). According to Stewart et al. (2008), this type of tourism could act as the main attraction for visiting a destination. Food tourism plays a significant role in the development of touristic destinations as a way of supplementing tourism (Kumar, 2019) and in tourists' decisions, since around 
one third of tourists' budgets are dedicated to purchasing local food including beverages and participating in related food activities (World Health Organization, 2015).

It is evident that the terms 'food tourism' primarily and 'gastronomy tourism' in second place are most commonly used instead of the terms 'culinary tourism' and 'cuisine'. Although the determination of the term 'local' for food remains inconsistent, it is preferred instead of conventional food by tourists seeking unique, original and quality characteristics.

Food traveller is strongly motivated to explore local food and beverages and to be engaged in gastronomic activities. Food tourism is more than a meal, and tourists would like to go backward. They are interested in exploring authenticity, tradition, culture, history of the local products, various food establishments and gastronomic destinations. They would like to taste local foods, overcome neophobia characteristics, learn about and prepare local dishes. They are delighted to hear food stories and storytellings, be very conscious of sustainability issues, meet local producers and residents, and live like a local.

All the above current trends are derived from a conceptual framework developed by considering the demand and supply perspective. Hence, a holistic approach is implemented by segmentation of three main categories: local food attributes, food service and destination characteristics. Food tourism approaches are developed considering local food tourism as an attraction for tourists, as a desire to increase their knowledge, to learn about the local culture, history, and authenticity, and as an opportunity to obtain food memorable experiences motivated by push and pull factors to select a food destination. Moreover, marketing initiatives and other factors such as beliefs, perceptions, desire, emotions, knowledge, involvement, image/brand name, satisfaction are analysed that influence behavioural outcomes with significant managerial and developmental implications.

\section{Literature review}

The definition of what is 'local' is not clear. Some food organisations define local food within a 100-mile radius from the production site, but this is not standard for every country (Meyerding et al., 2019). Main attributes of the local food which refer to quality (Di Vita et al., 2019; Marchini et al., 2014), labelling (Bencivenga et al., 2016), certifications (Madaleno et al., 2017), uniqueness (Kohsaka, 2017), sustainability (Barlagne et al., 2015; Schmitt et al., 2017), tradition, as well as sensory and health properties (Bryła, 2015; Ting et al., 2017), willingness to pay (WTP) (Berg and Preston, 2017), perceived authenticity (Kim et al., 2017), and neophilic characteristics (Ji et al., 2016), are widely examined and their preferences against global and familiar products are discussed, especially for specific market segmentations such as that involving demographic characteristics (López-Guzmán et al., 2014a, 2014b; Perez-Galvez, Granda et al., 2017; Sengel, et al., 2015), authenticity seekers (Özdemir and Seyitoğlu, 2017), experiencers (Cruz et al., 2019; Pérez-Gálvez et al., 2017a, 2017b), slow food members (Lee et al., 2015b) and 'snobbish' tourists (Lin et al., 2019).

The terms 'food tourism', 'gastronomic tourism', 'culinary tourism', and 'cuisine' are widely used and are also very often used interchangeably (Horng and Tsai, 2012). Since 2012, the term 'culinary tourism' has been replaced by the more accepted terms of 'food 
tourism' or 'gastronomic tourism' (Balderas-Cejudo et al., 2019). Hall and Sharples (2003) tried to differentiate the meanings of the above terms, stating that gastronomic and cuisine tourism refer to the tourists whose primary motivation for travel is the high interest in local food, whereas culinary tourism refers to tourists who have a moderate interest in local food, taking up food-related activities as a secondary motivation once they have arrived at a destination in the framework of a wider range of lifestyle activities. Tsai and Wang (2017) identified food tourism as the tourists covering all the range of interests.

Both gastronomy and culinary tourism include activities like visiting a local farm, restaurant and other food establishments that provide local specialties on their menus while they are linked with the cultural characteristics of the host destination (Richards, 2002). Ellis et al. (2018) concluded that 'food tourism' refers to food-related activities as physical and sensual experiences, 'culinary tourism' is linked to the cultural knowledge and consumption acquired via this physical experience and 'gastronomy tourism' concerns the place of food within the culture of the host region. All these categories have in common their interest in local food and related activities and the pursuing of authentic and memorable experiences (Balderas-Cejudo et al., 2019).

Food tourism, which could be used as an umbrella for all the above terms, could be segmented in more categories according to the specific attributes of local food products in the touristic destination place. Thus, different forms of special interest tourism connected with food have been developed, such as slow food tourism (Georgica, 2015; Lee et al., 2015b, 2014), halal food tourism (Al-Ansi and Han, 2019; Samori et al., 2016; Yousaf and Xiucheng, 2018), street food tourism (Chavarria and Phakdee-auksorn, 2017; Privitera and Nesci, 2015), gourmet tourism (Meneguel et al., 2019), ethnic food tourism (Mohammed et al., 2016; Ting et al., 2019), traditional food tourism ( $\mathrm{Ng}$ and Karim, 2016; Tanwar et al., 2018), salt tourism (Wu et al., 2015), olive oil tourism (Folgado-Fernandez et al., 2019; Millán-Vazquez de la Torre et al., 2017; Pulido-Fernandez et al., 2019), beer tourism (Di Matteo and Cavuta, 2016; Harrington et al., 2017; Kraftchick et al., 2014), wine tourism (Alebaki et al., 2015; Afonso et al., 2018; Byrd et al., 2016; Eustice et al., 2019; Garibaldi et al., 2017; Gómez et al., 2015a, 2015b; López-Guzmán et al., 2014a, 2014b; Martins et al., 2017; Pérez-Gálvez et al., 2017a; Song et al., 2019; Thanh and Kirova, 2018), agrotourism (Kim et al., 2019b), green tourism (Lita et al., 2014) and responsible tourism (Sin and Minca, 2014).

Several researches regarding food tourism have taken place in historical cities (Cruz et al., 2019; López-Guzmán et al., 2014a; Madaleno et al., 2017; Pérez-Gálvez et al., 2017a, 2017b; Sengel et al., 2015; Tsai and Wang, 2017; Yu and Sun, 2019), districts (Zhang et al., 2018), popular food and wine regions (Lourenço-Gomes et al., 2015; Mynttinen et al., 2015; Renna et al., 2015), villages (Xiong and Brownlee, 2018) and 'gastronomic' countries (Kohsaka, 2017; Littaye, 2016; Ng and Karim, 2016; Tanwar et al., 2018; Wijaya, 2019).

Regarding the characteristics and the behavioural intention of tourists, studies have taken place in food service establishments such as restaurants (Choe and Kim, 2019; Filimonau and Krivcova, 2017; Huang, 2017; Lu and Chi, 2018; Matson-Barkat and Robert-Demontrond, 2018; Sharma et al., 2014; Wu et al., 2019, 2016), Michelin restaurants (Kiatkawsin and Han, 2019; Meneguel et al., 2019; Vargas-Sánchez and López-Guzmán, 2018), luxury restaurants (Chen and Peng, 2018), 4 and 5 star hotel restaurants (Chen et al., 2016; Ismail et al., 2016; Peng et al., 2017), ethnic restaurants (Chatzopoulou et al., 2019; Kim et al., 2017; Liu and Mattila, 2015), green restaurants 
(Line et al., 2016), authentic restaurants (DiPietro et al., 2019), hot pot restaurants (Chen et al., 2014), pop-up restaurants (Taylor et al., 2018), upscale restaurants (Basri et al., 2016), fast food restaurants (Osman et al., 2014), hotels (Berbel-Pineda et al., 2019; Bondzi-Simpson and Ayeh, 2017), grocerants (Kim et al., 2019a), groceries (Kim et al., 2019b), premium food markets (Lee et al., 2019a), farmers' markets (Berg and Preston, 2017), food tourism factories (Chien et al., 2018), food trucks (Shin et al., 2019), breweries (Kraftchick et al., 2014), wineries (Alebaki et al., 2015; Byrd et al., 2016; Fernandes and Cruz, 2016; Martins et al., 2017; Park et al., 2019; Quintal et al., 2015), cellar door tasting rooms (McNamara and Cassidy, 2015), olive oil companies (Millán-Vazquez de la Torre et al., 2017), halal food establishments (Tama and Voon, 2014), universities (Campbell et al., 2014; Rahman and Reynolds, 2015) and festivals (Harrington et al., 2017; Lau and Li, 2019; Li et al., 2018; Muhammad et al., 2016a; Organ et al., 2015; Sung et al., 2016; Vajirakachorn and Chongwatpol, 2017; Vesci and Botti, 2019; Williams et al., 2015).

Table 1 Study's selected international journals

\begin{tabular}{llcc}
\hline No. & \multicolumn{1}{c}{ Titles of international journals } & $\begin{array}{c}\text { Number of } \\
\text { articles }\end{array}$ & $\begin{array}{c}\text { Percentage } \\
(\%)\end{array}$ \\
\hline 1 & Tourism Management & 26 & $16.15 \%$ \\
2 & International Journal of Hospitality Management & 24 & $14.91 \%$ \\
3 & Tourism Management Perspectives & 13 & $8.07 \%$ \\
4 & Journal of Destination Marketing \& Management & 13 & $8.07 \%$ \\
5 & Journal of Ethnic Foods & 10 & $6.21 \%$ \\
6 & Annals of Tourism Research & 7 & $4.35 \%$ \\
7 & Procedia - Social and Behavioral Sciences & 7 & $4.35 \%$ \\
8 & International Journal of Gastronomy and Food Science & 6 & $3.73 \%$ \\
9 & Wine Economics and Policy & 6 & $3.73 \%$ \\
10 & Journal of Business Research & 4 & $2.48 \%$ \\
11 & Appetite & 4 & $2.48 \%$ \\
12 & Procedia Economics and Finance & 4 & $2.48 \%$ \\
13 & Journal of Destination Marketing and Management & 3 & $1.86 \%$ \\
14 & Journal of Retailing and Consumer Services & 3 & $1.86 \%$ \\
15 & Heliyon & 3 & $1.86 \%$ \\
16 & Journal of Cleaner Production & 3 & $1.86 \%$ \\
17 & International Journal of Tourism Research & 2 & $1.24 \%$ \\
18 & Journal of Rural Studies & 2 & $1.24 \%$ \\
19 & Other journals (number of journals = 12) & 21 & $13.04 \%$ \\
Grand total & 161 & $100.00 \%$ \\
\hline
\end{tabular}

The choice of the food destination orientation depends on the tourists' motives (Afonso et al., 2018; Kim et al., 2019c; Kraftchick et al., 2014; Li et al., 2018; López-Guzmán et al., 2014b). Destination food image (Chang and Mak, 2018; Lai et al., 2018; Okumus and Cetin, 2018; Promsivapallop and Kannaovakun, 2019) is created by the initiatives of stakeholders' networks (Francioni et al., 2017; Musso and Francioni, 2015; Nguyen et al., 2019) to attract tourists by the appropriate marketing actions (Nelson, 2016; Jalis et al., 2014) that promote the culture (López-Guzmán et al., 2014a; Ng and Karim, 2016; Tanwar et al., 2018), history (Oktay and Sadikoglu, 2018a, 2018b), 
and authenticity (DiPietro et al., 2019; Le et al., 2019; Osman et al., 2014; Özdemir and Seyitoğlu, 2017) of the destination, food service and local food products. Moreover, experiences (Cruz et al., 2019; Huang, 2017; Pérez-Gálvez et al., 2017a, 2017b) could enhance satisfaction, and consequently, intentions to buy, visit and revisit a food service establishment and/or destination.

\section{Methodology}

In total, 161 articles from 30 international journals have been selected for the period 2014-2019. After a thorough examination of all the published articles, only the articles related to local agricultural products and food tourism were selected to be included in the analysis. Current trends of food tourism were pinpointed by distinguishing food tourism approaches in terms of attraction, knowledge, culture, history, authenticity, motives and experiences.

Moreover, a conceptual framework of food tourism management was developed by making segmentation in three main categories, namely brand attributes of local food products and food service/destination characteristics, taking into consideration the main factors that affect tourists' intentions to buy local food products, (re)visit food service establishments and food destinations, from both tourists and stakeholders' view.

\section{Food tourism approaches}

Food tourism as a broad category, including beverage, has been characterised recently as an attraction, as a desire for knowledge, to explore local culture, history, authenticity, and as the main motive to acquire experiences in touristic destinations (see also Table 2).

\subsection{Food tourism as an attraction}

Local food, cuisine, and gastronomy are quite often characterised as an attraction in the tourism industry. Pérez-Gálvez et al. (2017b) characterised gastronomy as an element of attraction in a tourist destination whereas Sengel et al. (2015) identified which tourists are interested in local food as an attraction after analysing the factors influencing local food demand in the tourism sector. While Lee et al. (2018) indicated that the factors involved in experiencing the cultural inheritance of local Taiwan cuisine through tourism include cultural attractions, cultural images, food histories, activity promotions, and experience functions, Kumar (2019) made a diversification among tourist attractions, stating that "cuisine is an attraction that is available year-round at any time of the day and does not very much depend on the weather conditions." Street food represents a significant tourist attraction in Thailand (Chavarria and Phakdee-auksorn, 2017), wine production in the Ningxia region is characterised as one of China's three major geographical attractions (Wang et al., 2018), while the city of Istanbul could be better marketed if culinary resources, domestic and international cuisines were promoted as a significant destination attraction (Okumus and Cetin, 2018). 


\subsection{Food tourism as a desire to learn}

Knowledge is an essential factor in food tourism since tourists are hungry for knowledge about different gastronomic places globally in the last years ( $\mathrm{Ng}$ and Karim, 2016), significantly influencing the decision-making process (Pillai et al., 2019). The desire to learn about the world of olive oil and olive areas is the main motivation of special interest tourism, namely olive oil tourism (Pulido-Fernandez et al., 2019), while for wine tourism, the primary reason of tourists who visit wineries is the desire to learn about the world of wine (López-Guzmán et al., 2014b). Knowledge of traditional culinary recipes and dishes could be seen as a chance for gastronomic innovation if new techniques are implemented in typical dishes to improve sensory and nutritional attributes (Renna et al., 2015). The protection of knowledge, based on a survey that took place in Michelin star restaurants in Spain, is stimulated by designing innovation techniques and creating gastronomical experiences (Vargas-Sánchez and López-Guzmán, 2018).

Table 2 Food tourism approaches - studies examined

\begin{tabular}{|c|c|c|c|}
\hline $\begin{array}{l}\text { Food tourism } \\
\text { approaches }\end{array}$ & $\begin{array}{c}\text { Number of studies } \\
\text { examined }\end{array}$ & & Authors \\
\hline \multirow{6}{*}{$\begin{array}{l}\text { Food tourism as } \\
\text { an attraction }\end{array}$} & \multirow[t]{6}{*}{6} & 1 & Chavarria and Phakdee-auksorn (2017) \\
\hline & & 2 & Kumar (2019) \\
\hline & & 3 & Okumus and Cetin (2018) \\
\hline & & 4 & Pérez-Gálvez et al. (2017b) \\
\hline & & 5 & Sengel et al. (2015) \\
\hline & & 6 & Wang et al. (2018) \\
\hline \multirow{11}{*}{$\begin{array}{l}\text { Food tourism as a } \\
\text { desire to learn }\end{array}$} & \multirow[t]{11}{*}{11} & 1 & Campbell et al. (2014) \\
\hline & & 2 & Eustice et al. (2019) \\
\hline & & 3 & Festa et al. (2016) \\
\hline & & 4 & Kiatkawsin and Han (2019) \\
\hline & & 5 & Li et al. (2018) \\
\hline & & 6 & López-Guzmán et al. (2014b) \\
\hline & & 7 & Ng and Karim (2016) \\
\hline & & 8 & Pillai et al. (2019) \\
\hline & & 9 & Pulido-Fernandez et al. (2019) \\
\hline & & 10 & Renna et al. (2015) \\
\hline & & 11 & Vargas-Sánchez and López-Guzmán (2018) \\
\hline \multirow{10}{*}{$\begin{array}{l}\text { Food tourism and } \\
\text { culture }\end{array}$} & \multirow[t]{10}{*}{12} & 1 & Choe and Kim (2018) \\
\hline & & 2 & Choe and Kim (2019) \\
\hline & & 3 & Georgica (2015) \\
\hline & & 4 & Jia (2020) \\
\hline & & 5 & Lee et al. (2019a) \\
\hline & & 6 & Lin et al. (2019) \\
\hline & & 7 & López-Guzmán et al. (2014a) \\
\hline & & 8 & Lourenço-Gomes et al. (2015) \\
\hline & & 9 & Meneguel et al. (2019) \\
\hline & & 10 & Mynttinen et al. (2015) \\
\hline
\end{tabular}


Table 2 Food tourism approaches - studies examined (continued)

\begin{tabular}{|c|c|c|c|}
\hline $\begin{array}{l}\text { Food tourism } \\
\text { approaches }\end{array}$ & $\begin{array}{c}\text { Number of studies } \\
\text { examined }\end{array}$ & & Authors \\
\hline \multirow{2}{*}{$\begin{array}{l}\text { Food tourism and } \\
\text { culture }\end{array}$} & \multirow[t]{2}{*}{12} & 11 & Ng and Karim (2016) \\
\hline & & 12 & Wijaya (2019) \\
\hline \multirow{13}{*}{$\begin{array}{l}\text { Food tourism and } \\
\text { history }\end{array}$} & \multirow[t]{13}{*}{13} & 1 & López-Guzmán et al. (2014a) \\
\hline & & 2 & Lourenço-Gomes et al. (2015) \\
\hline & & 3 & Madaleno et al. (2017) \\
\hline & & 4 & Mynttinen et al. (2015) \\
\hline & & 5 & Oktay and Sadikoglu (2018a) \\
\hline & & 6 & Oktay and Sadikoglu (2018b) \\
\hline & & 7 & Pérez-Gálvez et al. (2017b) \\
\hline & & 8 & Renna et al. (2015) \\
\hline & & 9 & Sengel et al. (2015) \\
\hline & & 10 & Tsai and Wang (2017) \\
\hline & & 11 & Xiong and Brownlee (2018) \\
\hline & & 12 & Yu and Sun (2019) \\
\hline & & 13 & Zhang et al. (2018) \\
\hline \multirow{5}{*}{$\begin{array}{l}\text { Food tourism and } \\
\text { authenticity }\end{array}$} & \multirow[t]{5}{*}{5} & 1 & Bryła (2015) \\
\hline & & 2 & Chatzopoulou et al. (2019) \\
\hline & & 3 & Le et al. (2019) \\
\hline & & 4 & Özdemir and Seyitoğlu (2017) \\
\hline & & 5 & Youn and Kim (2017) \\
\hline \multirow{6}{*}{$\begin{array}{l}\text { Food tourism and } \\
\text { motivations }\end{array}$} & \multirow[t]{6}{*}{6} & 1 & Afonso et al. (2018) \\
\hline & & 2 & Di Vita et al. (2019) \\
\hline & & 3 & Garibaldi et al. (2017) \\
\hline & & 4 & Kim et al. (2019c) \\
\hline & & 5 & Kraftchick et al. (2014) \\
\hline & & 6 & Yu and Sun (2019) \\
\hline \multirow{14}{*}{$\begin{array}{l}\text { Food tourism and } \\
\text { experiences }\end{array}$} & \multirow[t]{14}{*}{14} & 1 & Balderas-Cejudo et al. (2019) \\
\hline & & 2 & Chen et al. (2016) \\
\hline & & 3 & Cruz et al. (2019) \\
\hline & & 4 & Fernandes and Cruz (2016) \\
\hline & & 5 & Georgica (2015) \\
\hline & & 6 & Hendijani and Chern (2014) \\
\hline & & 7 & Huang (2017) \\
\hline & & 8 & Kim et al. (2019a) \\
\hline & & 9 & Matson-Barkat and Robert-Demontrond (2018) \\
\hline & & 10 & Pérez-Gálvez et al. (2017b) \\
\hline & & 11 & Privitera and Nesci (2015) \\
\hline & & 12 & Sin and Minca (2014) \\
\hline & & 13 & Tama and Voon (2014) \\
\hline & & 14 & Thanh and Kirova (2018) \\
\hline
\end{tabular}


Even in the marketing mix, specific knowledge plays a critical role from the transfer of the 4Ps model (product, price, promotion, place) in the wine marketing mix to the 4Es (expertise, evaluation, education and experience) in consumer purchase behaviour (Festa et al., 2016). In the food service sector, if both residents and tourists are highly involved in searching for food characteristics to acquire adequate knowledge from three menu stimuli (visual, verbal, stimuli control), then their attitudes will be positively affected, and the purchase intentions will be increased ( $\mathrm{Lu}$ and $\mathrm{Chi}, 2018$ ). On the other hand, gastronomic knowledge was not deemed to be a significant factor in explaining the WTP more for luxury food experiences (Kiatkawsin and Han, 2019). In a university foodservice environment, if students have sufficient knowledge concerning the attributes and the benefits of local products, it will enhance emotional interest; together with the high perceived product involvement, it will lead to an increase in the WTP for such products (Campbell et al., 2014). WTP will be increased in emerging wine regions and specifically in wine tasting rooms, even if there is limited knowledge about the geographic region (Eustice et al., 2019). In the Cherry Blossom Festival in the Tidal Basin area of the USA, enhancing tourists' knowledge/awareness about festival food characteristics is a significant priority to increase loyalty and intentions to revisit (Li et al., 2018).

\subsection{Food tourism and culture}

Local products are characterised as authentic, symbolising a specific place and culture (Madaleno et al., 2017). López-Guzmán et al. (2014a) in their research in the Sherry and Exrtamadura Spanish Regions concluded that food and wine are closely linked to culture since cuisine and culture are the resources which tourists' value most highly and desire most of all. Tourists are travelling from one country to another just to gain first-hand experience of local fare, which constitutes a part of cultural tourism ( $\mathrm{Ng}$ and Karim, 2016). Visitors who are better informed, of high income and educational level, with regard to the cultural landscape of World Heritage Sites, such as the Douro Wine Region in Portugal, are more willing to take part not only in wine cultural activities but in maintaining the cultural heritage of the area as well (Lourenço-Gomes et al., 2015). In the survey conducted in the South Savo Region of Finland, it was found that the typical motivators for the consumption of local food from tourists were associated with its culinary heritage and an authentic novel experience of local culture, and not with environmental and economic topics (Mynttinen et al., 2015).

After designing an Indonesian food cultural map, Wijaya (2019) claimed that promoting Indonesian culinary tourism as special interest tourism should not only focus on the ample varieties of the traditional food but also the socio-cultural values behind the food itself, which should be more significantly emphasised. The Slow Food Movement is also characterised as a cultural initiative since it aims to preserve traditional food preparation methods, meals, local farming and cuisine (Georgica, 2015). In a survey that took place in restaurants of Hong Kong regarding the cultural background and consumption intentions of tourists in the food service sector, the foreign tourist's satisfaction with tasting local food varied by cultural region, and the cultural profile of tourists partially moderates the relationships between the effect of tourists' local food consumption value on their perceptions and behaviours (Choe and Kim, 2019, 2018). Jia (2020) came up with similar conclusions stating that tourists with different cultural 
backgrounds think and behave differently concerning motivation and satisfaction in restaurants. On the other hand, Lin et al. (2019) implemented a cultural taste analysis to examine tourists' food consumption by making a segmentation of tourists of those who treat different products equally (omnivorous taste) and those who have a hierarchical attitude (distinctive taste). According to Meneguel et al. (2019), Michelin restaurants are providers of cultural elements by sharing the role along with other segments of the cultural industry through the transfer of overall experiences of cultural impressions of destiny. Cultural perspective, together with the duration of experience, should also be taken very carefully into consideration, concerning whether the unique value that consumers place on premium food markets significantly influence (or not) affective commitment (Lee et al., 2019a).

\subsection{Food tourism and history}

Recognition of the healthy culinary, nutritional model of the Mediterranean diet and the Mediterranean regions' lifestyle is linked with cultural heritage and the history of each area (Renna et al., 2015). Oktay and Sadikoglu (2018a, 2018b) analysed the gastronomic cultures' impact on the African, Russian, Azerbaijani and Iranian cuisines through a literature review, pinpointing that historical cultural relations play a very important role when evaluating the countries' cuisines. Emphasising the unique value of history, Bryła (2015) stated that "We could copy all aspects of a food product, but it is impossible to change its history." The significance of history is highlighted as well from the high interest shown by tourists who prefer to visit historic cities to taste local agricultural products and gastronomy such as Caceres in Spain (López-Guzmán et al., 2014a), Tainan in Taiwan (Tsai and Wang, 2017), Oruro in Bolivia (Cruz et al., 2019), Cuena in Ecuador (Pérez-Gálvez et al., 2017a), Lima in Peru which is considered one of the main gastronomic leaders globally (Pérez-Gálvez et al., 2017b), Istanbul in Turkey (Sengel et al., 2015), the cities of Lisbon, Oporto, and Coimbra in Portugal which are included in the UNESCO World Heritage Sites (Madaleno et al., 2017), and Macau in Taiwan which is designated as the Creative City of Gastronomy since 2017 (Yu and Sun, 2019). Moreover, traditional multicultural villages such as Kampongs in Singapore (Xiong and Brownlee, 2018), historic districts such as the Confucian Temple of Nanjing (Zhang et al., 2018), historic regions such as the South Savo of Finland (Mynttinen et al., 2015) and the Demarcated Douro Region, one of the oldest demarcated wine regions globally, which is included in the list of World Heritage Sites (Lourenço-Gomes et al., 2015), are also in tourists' destination priorities.

\subsection{Food tourism and authenticity}

Authenticity is strongly correlated with the purchase and consumption of local food and the participation and involvement of relative activities. In their conceptual study, Özdemir and Seyitoğlu (2017) made a segmentation of tourists in three categories, namely comfort, moderates and authenticity seekers, with the last group be the one consisting of people who are seeking authenticity in new food image destinations, consuming unfamiliar and novel local food, dining at authentic restaurants, participating and being actively involved in food activities, festivals and events, with the desire to learn more about local culture, tradition and characteristics. Bryła (2015) stated that the perceived authenticity of a product is characterised by its origin, which includes place, 
history, local community, and the raw/natural materials, while unfamiliar local ingredients, unique food names, and storytelling about the origins of food increase consumers' perceptions of authenticity, which in turn enhance satisfaction and purchase intentions, especially for ethnic restaurants (Youn and Kim, 2017). The incorporation of notions of authenticity into the orders of worth is examined by Chatzopoulou et al. (2019) in ethnic Greek restaurants by making a segmentation of customers to determine 'hot' authentication, while Le et al. (2019), in their review paper, focused on examining the authenticity of things and the authenticity of the self (demand) in restaurants by conceptualising the authenticity of the organisation (supply) to enhance the knowledge and the determinants of authenticity.

\subsection{Food tourism and motivations}

Motives could be categorised as primary and secondary, push and pull factors, or internal and physical characteristics. Gastronomy is considered one of the main motivations of travellers who select a specific destination (Garibaldi et al., 2017). Yu and Sun (2019) stated that motivation is related to tourists' satisfaction from the experiences that influence their perceptions towards the destinations. Kim et al. (2019c) used an inductive phenomenological approach to discover the critical motives of Japanese tourists who visit a village. In the wine sector, consumers' motivation changes accordingly with the level of the wine quality (Di Vita et al., 2019). Afonso et al. (2018) showed that primary motives such as core wine and education should be combined with a secondary motive such as participation in wine events and festivals, in order to increase the intention to return, while in a beer festival, only physical pull factors such as brewery experiences were significant for beer-seeking tourists (Kraftchick et al., 2014).

\subsection{Food tourism and experiences}

Tourism is characterised as one of the leading sectors for exploring customer experience (Matson-Barkat and Robert-Demontrond, 2018). Tourists visiting distant places are interested in 'going local', having an authentic experience with local people and communities (Sin and Minca, 2014). In the last years, there is an increase in the number of travellers, who will travel even very far away in order to seek gastronomic experiences, the so-called gastronomes, foodies or food hunters, whose primary reason for travelling is food. In their study in Malaysia, Hendijani and Chern (2014) revealed that food hunting for gastronomes could be characterised as a psychological process starting from childhood, acquiring food experiences; due to those memories, they are motivated to continue seeking new ones. These food activity memories are coming back period by period for 'slow' tourists, characterising slow travel not as a specific mode of transportation but as a mindset (Georgica, 2015).

Regarding food services, the study of Kim et al. (2019a) was the first attempt to examine customer experience at grocerants (groceries and restaurants) in Korea; as a new form of food service that can maintain a competitive advantage, based on the experience economy, it emphasised the importance of delivering unique and memorable experiences associating the positive effects of entertainment and escapist experiences on brand prestige, customer perceived value and the influence of functional, hedonic, financial (and not social) aspects to loyalty. Entertainment dimensions were also predominant 
together with educational ones in the experience economy model that was used in wine regions of France to examine wine tourism experiences (Thanh and Kirova, 2018), while experience quality not only has a significant influence on customers' loyalty satisfaction and intention to revisit wineries in Portugal, but it is also the case that derived memorable experiences could attract new customers through recommendations by word-of-mouth (Fernandes and Cruz, 2016).

In their survey carried out in Sarawak of Malaysia, Tama and Voon (2014) identified six components of customer emotional experience, namely spiritual assurance, pleasure, arousal, dominance, joy, and acceptance, related to halal food establishments that are significantly associated among each other and could enhance positive behavioural intentions. Street vendors, especially street food, contribute to authentic touristic gastronomic experiences, linking together food, place and tourism (Privitera and Nesci, 2015).

Concerning the degree of gastronomic experience, several segmentations of tourists are made. The older gastronomic tourists' group are considered as senior foodies, a niche market, who, especially the new generation, are very experienced travellers, have time and money to search, taste and buy local food products of high-quality, prefer superior services and are interested in unique experiences (Balderas-Cejudo et al., 2019). The most common segmentations are usually in three categories: survivors, enjoyers and experiencers, where the last are more interested in local gastronomy and similar activities. Valuable results have come out from different surveys conducted in Latin America. For example, in Bolivia, the experiencers link gastronomy with a cultural heritage for higher satisfaction (Cruz et al., 2019). On the other hand, in Lima of Peru, one of the gastronomical centres worldwide, the culinary motivations of experiencers regarding new food experiences and socialisation, and not the connection with cultural food heritage, contribute significantly to gastronomic satisfaction (Pérez-Gálvez et al., 2017b). Finally, tourists' dining experiences in Taiwan, specifically experiential value, can be affected positively by chefs' image, staff service quality, and interaction with other customers in 4 and 5 star hotel restaurants (Chen et al., 2016), while differences in dining experiences for specialty local foods were observed between foreigners and local tourists in China, which are explained based on a content analysis from the cultural and contextual variables (Huang, 2017).

\section{A conceptual framework of food tourism management}

The ultimate target of tourists is to buy, visit or recommend depending on whether there is a food product, a food service, or a destination under examination. Based on their motives, tourists select a food destination to visit, a food service establishment to visit, and specific local food products to consume. In those environments, culture, history, and authenticity are already present there. Still, local stakeholders, together with the active involvement of residents, should take up the necessary and effective marketing activities in order to promote and enhance the image of the destination/food service and the brand name of the local food and beverage products. By considering different characteristics and values of those environments, together with beliefs (attitudes, subjective norms, perceived behaviour control), perceptions, emotions, desires, and other tourist characteristics, the intentions to buy, visit and recommend are successfully examined. Moreover, experiences acquired during tourists' visits to those environments could affect 
the corresponding intentions depending on the level of satisfaction. On the other hand, by also developing the appropriate marketing policies by stakeholders' network, together with the responsible behaviour of tourists, who have obtained an adequate level of knowledge, are well aware of and actively involved in all these aspects, a solid food tourism management could successfully be adopted and implemented.

\subsection{Tourists'approach}

Tourists' behavioural outcomes are analysed based on three segmentation categories: tourists' intentions to purchase local food products, (re)visit and recommend food services, and (re)visit and recommend food destinations. The first category is considered a subtotal of the second category whereas the first two categories are considered a subtotal of the third category.

\subsubsection{Local food attributes/brand and intentions to consume/buy/recommend}

Tourists' intentions to consume/buy and recommend local food depend on local food attributes such as quality, freshness, identity, symbolic, locality, utility, price, health, sensory, safety concerns and table manners either directly through tourists' beliefs (attitudes, subjective norms, perceived behaviour control), emotions, desires, perceptions or indirectly though experiences and satisfaction.

The characteristics and attributes of local food are significant for travellers and consumers and much more substantial than motivational factors such as health concerns, cultural experiences, excitement, interpersonal relations and sensory appeal (Madaleno et al., 2017). Moreover, based on the findings of Wu et al. (2016), communication and sensory appeal are not important either in predicting tourists' attitudes toward local food as well. On the contrary, according to Bryła (2015), the characteristics that differentiate origin from conventional food depend mainly on sensory and health considerations, and links with local tradition, while Ting et al. (2017) showed that only health properties and sensory appeal could positively affect the intention to consume ethnic food for non-Dayak Malaysians. Health characteristics of agricultural products are ranked first among health-conscious consumers who are seeking organic rather than conventionally grown food in order to improve their quality of life (Rana and Paul, 2017), while the characteristics of healthiness and freshness of local products were especially valued as well by Russian tourists in Finland (Mynttinen et al., 2015). Batat et al. (2019) tried to connect health and the pleasure of food, stating that healthy eating should be considered through the utility of food as pleasure rather than as a health deterrent that could lead to consumers' food well-being. Lin and Mao (2015) advocated the view that sensory, symbolic, and utility attributes are the main characteristics of food specialties and souvenirs in order to be distinguished with an award, while Eustice et al. (2019) stated that sensory information provided in messages concerning wines had no impact on WTP. In contrast, wine awards/prizes contributed to a very high level of WTP. On the other hand, most consumers were sceptical and critical about wine awards. Only those wines with the gold medal or the most prestigious characteristic will positively affect their decision-making (Neuninger et al., 2017). 
Table 3 Tourists' approach - studies examined

\begin{tabular}{|c|c|c|c|}
\hline $\begin{array}{l}\text { Tourists' approach } \\
\text { thematic areas }\end{array}$ & $\begin{array}{c}\text { Number of } \\
\text { studies examined }\end{array}$ & & Authors - research studies \\
\hline \multirow{20}{*}{$\begin{array}{l}\text { Local food } \\
\text { attributes/brand and } \\
\text { intentions to } \\
\text { consume/buy/recommend }\end{array}$} & \multirow[t]{20}{*}{20} & 1 & Adongo et al. (2015) \\
\hline & & 2 & Alderighi et al. (2016) \\
\hline & & 3 & Batat et al. (2019) \\
\hline & & 4 & Berg and Preston (2017) \\
\hline & & 5 & Casini et al. (2016) \\
\hline & & 6 & Chavarria and Phakdee-auksorn (2017) \\
\hline & & 7 & Eustice et al. (2019) \\
\hline & & 8 & Filimonau and Krivcova (2017) \\
\hline & & 9 & Kim et al. (2019b) \\
\hline & & 10 & Lang and Lemmerer (2019) \\
\hline & & 11 & Madaleno et al. (2017) \\
\hline & & 12 & Meng and Choi (2016) \\
\hline & & 13 & Meyerding et al. (2019) \\
\hline & & 14 & Mynttinen et al. (2015) \\
\hline & & 15 & Neuninger et al. (2017) \\
\hline & & 16 & Rana and Paul (2017) \\
\hline & & 17 & Schmitt et al. (2017) \\
\hline & & 18 & Ting et al. (2017) \\
\hline & & 19 & Wu et al. (2016) \\
\hline & & 20 & Zhou et al. (2019) \\
\hline \multirow{17}{*}{$\begin{array}{l}\text { Foodservice } \\
\text { characteristics/image and } \\
\text { intentions to } \\
\text { revisit/recommend }\end{array}$} & \multirow[t]{17}{*}{37} & 1 & Basri et al. (2016) \\
\hline & & 2 & Bondzi-Simpson and Ayeh (2017) \\
\hline & & 3 & Byrd et al. (2016) \\
\hline & & 4 & Chen and Peng (2018) \\
\hline & & 5 & Chen et al. (2014) \\
\hline & & 6 & Chien et al. (2018) \\
\hline & & 7 & DiPietro et al. (2019) \\
\hline & & 8 & Harrington et al. (2017) \\
\hline & & 9 & Ismail et al. (2016) \\
\hline & & 10 & Kiatkawsin and Han (2019) \\
\hline & & 11 & Kim et al. (2019d) \\
\hline & & 12 & Lau and Li (2019) \\
\hline & & 13 & Lee et al. (2019a) \\
\hline & & 14 & Lita et al. (2014) \\
\hline & & 15 & Liu and Mattila (2015) \\
\hline & & 16 & Lu and Chi (2018) \\
\hline & & 17 & $\begin{array}{l}\text { Matson-Barkat and Robert-Demontrond } \\
\text { (2018) }\end{array}$ \\
\hline
\end{tabular}


Table 3 Tourists' approach - studies examined (continued)

\begin{tabular}{|c|c|c|c|}
\hline $\begin{array}{l}\text { Tourists' approach } \\
\text { thematic areas }\end{array}$ & $\begin{array}{c}\text { Number of } \\
\text { studies examined }\end{array}$ & & Authors - research studies \\
\hline \multirow{20}{*}{$\begin{array}{l}\text { Foodservice } \\
\text { characteristics/image and } \\
\text { intentions to } \\
\text { revisit/recommend }\end{array}$} & \multirow[t]{20}{*}{37} & 18 & McNamara and Cassidy (2015) \\
\hline & & 19 & Muhammad et al. (2016) \\
\hline & & 20 & Organ et al. (2015) \\
\hline & & 21 & Osman et al. (2014) \\
\hline & & 22 & Park et al. (2019) \\
\hline & & 23 & Peng et al. (2017) \\
\hline & & 24 & Quintal et al. (2015) \\
\hline & & 25 & Rabbiosi (2016) \\
\hline & & 26 & Samori et al. (2016) \\
\hline & & 27 & Sengel et al. (2015) \\
\hline & & 28 & Shin et al. (2019) \\
\hline & & 29 & Sung et al. (2016) \\
\hline & & 30 & Taylor et al. (2018) \\
\hline & & 31 & Thomas-Francois et al. (2017) \\
\hline & & 32 & Ting et al. (2019) \\
\hline & & 33 & Tsai and Wang (2017) \\
\hline & & 34 & Vajirakachorn and Chongwatpol (2017) \\
\hline & & 35 & Vesci and Botti (2019) \\
\hline & & 36 & Williams et al. (2015) \\
\hline & & 37 & Wu et al. (2019) \\
\hline \multirow{15}{*}{$\begin{array}{l}\text { Gastronomic } \\
\text { characteristics/image of a } \\
\text { destination and intentions } \\
\text { to revisit/recommend }\end{array}$} & \multirow[t]{15}{*}{15} & 1 & Berbel-Pineda et al. (2019) \\
\hline & & 2 & Björk and Kauppinen-Räisänen (2019) \\
\hline & & 3 & Chang and Mak (2018) \\
\hline & & 4 & Folgado-Fernandez et al. (2019) \\
\hline & & 5 & Gómez et al. (2015a) \\
\hline & & 6 & Jalis et al. (2014) \\
\hline & & 7 & Gómez et al. (2015b) \\
\hline & & 8 & $\operatorname{Kim}(2014)$ \\
\hline & & 9 & Lee et al. (2019b) \\
\hline & & 10 & Marchini et al. (2014) \\
\hline & & 11 & Omar et al. (2015) \\
\hline & & 12 & Pérez-Gálvez et al. (2017a) \\
\hline & & 13 & Privitera and Nesci (2015) \\
\hline & & 14 & Promsivapallop and Kannaovakun (2019) \\
\hline & & 15 & Tsai and Wang (2017) \\
\hline
\end{tabular}


Figure 1 A conceptual framework of food tourism management (see online version for colours)

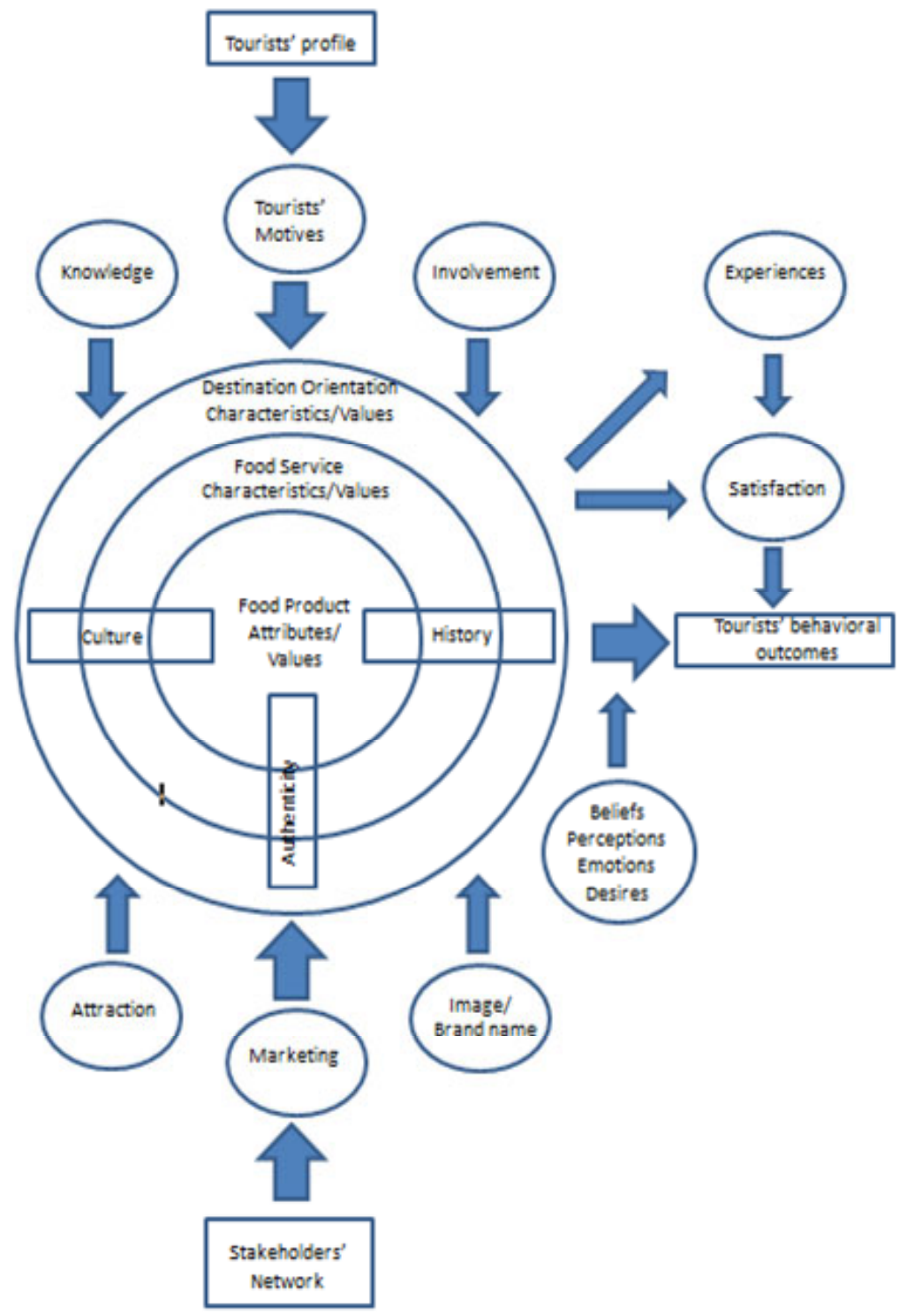

Antecedents may better explain and forecast attitudes and behaviours towards local foods, the benefits from local food, and how consumers define local food (Lang and Lemmerer, 2019). According to Schmitt et al. (2017), distance from the production site was not important, and other characteristics of locality such as identity, control of local actors, and know-how were proved to be more crucial factors. The production site does not seem to play a significant role in the study of Casini et al. (2016) about olive oil, since only one-fourth of the sample showed a preference for the region of origin, and the remaining percentage made their choices mainly by price. In their survey in Germany, Meyerding et al. (2019) discovered that consumers prefer local products, fresh and processed, irrespectively of the exact production and distance to consumers' home. 
According to age and income characteristics, consumers are willing to substitute non-local for local food when the price is appropriate (Berg and Preston, 2017), while other consumers could pay a higher price for food only if the perceived quality is higher (Filimonau and Krivcova, 2017). Subjective norms and perceived behaviour control also affect behaviour intention in consuming unfamiliar local food in the USA by Chinese tourists, whereas safety concerns and table manners, depending on individual beliefs, affect tourists' attitudes towards local food (Wu et al., 2016). Perceived behaviour control and affection and satisfaction were the factors better predicting tourists' behavioural willingness for local street food in Phuket (Chavarria and Phakdee-auksorn, 2017). In contrast, perception of authenticity was found to be a significant predictor for slow tourism behavioural intentions in Korea after using an extended theory of planned behaviour (TPB) incorporating the theory of reasoned action (Meng and Choi, 2016). Local food specialties could also be found outside the place of origin in food stores, permitting future travellers to taste local traditions and enhance the perceived authenticity of the place of origin (Alderighi et al., 2016).

Memorable experiences such as cultural, innovative, educational, hedonic, and adverse experiences can significantly affect tourists' willingness to recommend local foods (Adongo et al., 2015). Nostalgic labels increase consumers' purchase and consumption intentions as well by emphasising the role of emotion that connects memories with past experiences (Zhou et al., 2019). The development of emotional attachment with agroproducts could also be promoted with agrotourism by enhancing the post-purchase behaviour after tourists have been involved in various agrotouristic activities that could also contribute to the economic sustainability of an area when there is a long-term approach since the corresponding economic benefits via post-purchase behaviour are much more significant (Kim et al., 2019b).

\subsubsection{Foodservice characteristics/image and intentions to revisit/recommend}

Researches of branding food service in food tourism are limited (Tsai and Wang, 2017). Tourists' attitudes toward environmentally friendly services has significant influence on the overall image of hotels and restaurants, which in turn significantly affects revisit intentions, positive word-of-mouth and WTP more for green hotels and restaurants (Lita et al., 2014). Although tourists may have a low interest in local food consumption in 4 and 5 star hotels compared to lower star hotel accommodations (Sengel et al., 2015), brand attributes such as physical relationships and reflection, together with high food quality, could improve a high star hotel's image (Ismail et al., 2016). In luxurious restaurants, interpersonal influence such as the 'snob effect', the 'bandwagon effect' and personal influence such as hedonic effects affect prestige consumption (Kiatkawsin and Han, 2019), while perceived hedonic value, together with perceived functional value and perceived symbolic/expressive value, may influence tourist consumers' attitudes to dine at luxury restaurants (Chen and Peng, 2018). The positive influence of prestige values (conspicuous, social, emotional and quality) on affective commitment will, in turn, affect the revisit intention to premium food markets (Lee et al., 2019a). Subjective norms in the first place and perceived customer patronage in second place were the most significant factors influencing intentions towards the inclusion of indigenous dishes on the menus of small and medium hotels in Ghana (Bondzi-Simpson and Ayeh, 2017). In contrast, although tourists seem to have lots in commons in consumption intention in Malaysia, they differ in the way they intend to consume Dayak local food (Ting et al., 2019). 
Hedonic values, such as entertainment and emotional worth, were found to be the most significant factors that influence consumer intention to visit food trucks, whereas utilitarian values, such as instrumental and rational worth, affect only indirectly the intentions by enhancing consumers' attitudes (Shin et al., 2019). Integrated interpretations of performative approaches were used by Rabbiosi (2016) for the branding of local food and wine shops. Restaurant stimuli such as food quality, chef's image and service quality can influence both the positive and negative emotions of customers and in turn loyalty (Peng et al., 2017); perceived authenticity affects positive emotions (Kim et al., 2017), while an authentic menu together with the psychological needs 'to belong and to be unique' increase the satisfaction and loyalty of customers in ethnic restaurants (Liu and Mattila, 2015). Single customers' satisfaction, trust, and commitment to single friendly restaurants in Taipei City, Taiwan depend on restaurant attachment dimensions and experiential relationship intentions (Wu et al., 2019), whereas the positive relationship between customer satisfaction with wine promotion, which significantly affects behavioural intention in Korean restaurants, depends on customers' gender and age (Kim et al., 2019d). Educated staff and social connection with the employees are the top restaurants attributes that repeat tourists appreciate, enhancing the loyalty of the place as well (DiPietro et al., 2019), while in the study of a historic winery in Spain, the revisit intention for highly satisfied tourists takes a higher number of repeat visits in order to start decreasing, following the inverted U-shape relationship (Park et al., 2019).

Restaurant image and experiential value are very important factors that affect consumption intention in nostalgic hot pot restaurants in Taiwan, especially nostalgic emotions, which can attract tourists even before the experience takes place (Chen et al., 2014), while the experiential value of pop-up restaurants results in increased standards of relationship quality, satisfaction, trust, positive WOM recommendations, return visits and an increased intention of WTP towards pop-up dishes in the USA (Taylor et al., 2018). Physical environment quality is considered the most critical factor that influences most word-of-mouth towards purchase decisions in upscale Malay restaurants (Basri et al., 2016), while WTP for wine tasting in cellar doors depends on the simultaneous offer of local products and the deduction of the corresponding cost if wine is purchased (McNamara and Cassidy, 2015). The need to increase awareness and issue certificates on halal restaurants and hotels could improve their image and tourists' intention to revisit, especially in small Asian cities (Samori et al., 2016). International chain branded spaces of hospitality, such as Mc-Donalds, located a little further away from the main touristic centres, could result in positive tourist experiences by enjoying both the authentic cultural characteristics of the destination and the corresponding atmosphere of the globalised branded hospitality (Osman et al., 2014).

The value of co-creation and co-production of local food has been analysed by Thomas-Francois et al. (2017) using service-dominant logic and mind map techniques to examine their influence on the supply chain of food service establishments. In particular, the role of co-production is being emphasised in restaurants by co-producing social meanings among customers' interaction, service staff and chefs, enhancing at the same time social meanings of family togetherness and sharing experiences (Matson-Barkat and Robert-Demontrond, 2018) as well as in the development of food factories, which together with image congruence, positively influence trust and unplanned purchases of food factory products (Chien et al., 2018).

Regarding festivals, the determinants of satisfaction and its relation with revisit intention are mostly examined in the papers. Positive relations were identified between 
perceived value and perceived quality in satisfaction, which in turn positively affects the intention to revisit Amis Harvest Festival and Hualien in Taiwan (Sung et al., 2016), while Vajirakachorn and Chongwatpol (2017), in their study of a local food festival in Thailand, used a business intelligence framework to analyse the perceived value, perceived quality, and satisfaction, together with 27 other attributes, to explain and forecast revisit intentions. Attribute performance, together with culture and atmosphere, played a significant role in tourists' satisfaction of Oktoberfest in Munich, the most famous beer festival worldwide (Harrington et al., 2017). The level of satisfaction and revisit intentions were also examined in the Rumah Terbuka Aidilfitri celebration in Perak, Malaysia, with the majority of visitors stating that they will recommend it to others as well (Muhammad et al., 2016). Slow food festival in Melbourne explored the way virtue ethics influence foodways (Williams et al., 2015). Engagement and positive emotions in Welsh food festivals were considered to be good predictors of post-behavioural intention months later (Organ et al., 2015). Urban festivals and environmental, social, and ideological place-making dimensions were explored by Lau and $\mathrm{Li}$ (2019) in their attempt to define a unique notion of place. In a survey of wine events that took place in France and Spain, depending on the method used, SEM findings showed that intention to return is affected positively only by participation and involvement, while the fsQCA findings showed that these factors cannot be seen independently and should be combined with core wine and education (Afonso et al., 2018). Lu and Chi (2018) implemented an approach that encourages the active involvement of tourists in local food and related activities by organising educational and entertaining events on the premises.

In the Campania Region of Italy, it was found that attitude was the most significant element that affects intention to revisit local small culinary festivals with the food and beverage quality having the most influential factor on tourists' attitudes (Vesci and Botti, 2019), while in wineries in Australia and the USA, service staff, complementary products together with winescape setting and wine value, were considered to be significant attributes that influence wine tourists' attitudes towards the behavioural intentions of wineries (Quintal et al., 2015). The significance of customer service was proven to be the primary predictor of repeating visits at wineries, contributing to economic development as well, since they support sustainable revenue for small and medium wineries in the area (Byrd et al., 2016).

\subsubsection{Gastronomic characteristics/image of a destination and intentions to revisit/recommend}

Little is known about the attributes that characterise gastronomic image from tourists' point of view (Chang and Mak, 2018). Kim (2014) developed a scale development procedure with attributes that influence memorable tourism experiences in a tourism destination. Omar et al. (2015) showed that the involvement in food culture and the perceived importance of local heritage food influence the loyalty of international tourists in the sense of revisiting Malaysia, while Chang and Mak (2018), after using a repertory grid method and generalised Procrustes analysis, claimed that flavour profile, familiarity, distinctiveness, convenience and price are the most significant GI attributes in Taiwan. Destination food image factors such as unique cultural experience, health and hygiene, restaurant service, food taste, variety and eating manners were found to have more 
influence on food preference than food consumption, varying by the nationality of the tourists as well as excluding food taste image (Promsivapallop and Kannaovakun, 2019).

Moreover, in Tainan, a historical city of Taiwan, selling traditional street food, consumer return on investment (CROI) was considered to be a key attribute in the evaluation of experiential value, which could improve a place's image, which in turn influences the intention to revisit (Tsai and Wang, 2017). On the other hand, in Italy, street food could contribute significantly to the image of a region, but street vendors should be trained better in food preparation (Privitera and Nesci, 2015).

Food triggers travel motivation, influences the choice of the tourist destination and the gastronomic experience, and affects satisfaction, decision behaviour, and the intention to revisit a destination (Berbel-Pineda et al., 2019; Björk and Kauppinen-Räisänen, 2019). Ji et al. (2016) showed that food satisfaction that affects intentions to revisit and recommendations depends on food personality traits such as neophobic/neophiliac tendencies and on the mediating role of novelty seeking and food consumption. Overall experiences could also be predicted significantly from the food perceptions of tourists regarding the identity and the emotional image of the territory (Folgado-Fernandez et al., 2019). In Cuenca of Equator, greater preference and appreciation of high-quality local cuisine is made by tourists who have higher education and income level and a higher intention to revisit (Pérez-Gálvez et al., 2017a).

According to Alderighi et al. (2016), local food image destination and intention to revisit also depend on how well its place of origin characterises a local food product. This will reduce the intention to revisit other similar destinations (business stealing effect). Moreover, destination image could influence product evaluation over time because of the halo effect, depending on the level of knowledge and high involvement of tourists in food activities (Lee et al., 2019b). Higher numbers of agricultural enterprises, together with the age of the products' destination of origin and the large number of investments in marketing will increase the collective reputation of the product which will lead to the enhancement of the destination image of an area (Marchini et al., 2014). Moreover, a strong food destination image could act as a significant factor in competitive advantage against other destinations with similar characteristics (Chang and Mak, 2018; Jalis et al., 2014). The relationship between the image of a wine area and destination brand equity, also taking into account the brand image, was also tested in five wine regions of Spain as a chance to attract tourists (Gómez et al., 2015a); by asking stakeholders and tourist groups, it was found that winery managers evaluate more positively the above characteristics than visitors (Gómez et al., 2015b).

\subsection{Stakeholders' approach}

Stakeholders such as farmers, producers, distributors, foodservice managers, policymakers, and residents should actively cooperate by creating a stakeholders' network, which could enhance marketing initiatives to promote the touristic image and attraction of the local food product, food service place and destination.

\subsubsection{Stakeholders' network}

Over the last two decades, there is an increase in research concerning wine tourism, but the majority of the articles are focused on the demand side (tourists) rather than the supply (local stakeholders) side (Soontiens et al., 2018). Research shows that there is a 
lack of cooperation among local producers (Francioni et al., 2017), lack of adequate representation in decision-making at the societal level (Soontiens et al., 2018), inability for internalisation of local food firms (Francioni et al., 2017; Musso and Francioni, 2015), absence of effective involvement of residents in wine trails (Xu et al., 2016), absence of various agents in olive oil routes (Millán-Vazquez de la Torre et al., 2017) and lack of tour operators (Garibaldi et al., 2017).

Table 4 Stakeholders' approach - studies examined

\begin{tabular}{lcc}
\hline $\begin{array}{l}\text { Stakeholders' } \\
\text { approach }\end{array}$ & Number of studies examined & Authors \\
\hline Stakeholders' & 1 & Björk and Kauppinen-Räisänen (2019) \\
network & 2 & Francioni et al. (2017) \\
3 & Garibaldi et al. (2017) \\
4 & Kohsaka et al. (2016) \\
5 & Millán-Vazquez de la Torre et al. (2017) \\
6 & Musso and Francioni (2015) \\
7 & Soontiens et al. (2018) \\
8 & Szpilko (2017) \\
9 & Wu et al. (2015) \\
10 & Xiong and Brownlee (2018) \\
11 & Xu et al. (2016) \\
12 & Al-Ansi and Han (2019) \\
Food tourism & 13 & Jalis et al. (2014) \\
marketing & 14 & Jong and Varley (2017) \\
15 & Lai et al. (2018) \\
16 & Martins et al. (2017) \\
17 & Nelson (2016) \\
18 & Okumus and Cetin (2018) \\
19 & Thach and Olsen (2015) \\
20 & Wong et al. (2019) \\
21 & Yousaf and Xiucheng (2018) Sun (2019) \\
\hline & & \\
& &
\end{tabular}

The creation of a local network of key stakeholders is essential for promoting food tourism and the tourism development of the regions and the enterprises that could act as a competitive advantage against other similar competitors (Szpilko, 2017; Musso and Francioni, 2015). Coordination and voice mechanisms could contribute to the effectiveness of knowledge sharing and mutual understanding, leading to collaboration among the stakeholders (Soontiens et al., 2018). Local networks could contribute significantly to the internalisation of winemakers (Musso and Francioni, 2015), especially when there are small wine producers; a personal network of relationships could then be developed with tourists in the first place and with friends and relatives, expatriates, and other business partners as well (Francioni et al., 2017). Moreover, local networks could assist in the innovation of local food products (Szpilko, 2017) and solve proximity 
difficulties in an urban target market when local industry is located in rural areas (Soontiens et al., 2018).

The engagement of local people with tourists is a crucial factor in the promotion of food tourism, acting as part-time marketers, by creating suitable destination places where tourists could have memorable food experiences (Björk and Kauppinen-Räisänen, 2019), while participatory experiences with the involvement of local residents also seems to influence tourists' perceptions in salt tourism destinations (Wu et al., 2015). Moreover, adequate management of social networks, will assist in the transmission and preservation of knowledge attributes and production methods from generation to generation (Kohsaka et al., 2016) by taking into account positive memories of socialisation practices concerning sharing and togetherness that could improve healthiness and food security (Xiong and Brownlee, 2018). Furthermore, local residents' levels of perceptions and satisfaction could affect the promotion of wine tourism, such as wine trails accordingly, in terms of personal benefits and social impact (Xu et al., 2016). The involvement of various agents in olive oil routes (Millán-Vazquez de la Torre et al., 2017) and the cooperation of tour operators with local stakeholders could satisfy the needs of any tourists combining gastronomy with a high degree culture and other food activities (Garibaldi et al., 2017).

\subsubsection{Food tourism marketing}

Successful marketing of a destination was made in Houston, Texas, USA, which has acquired national recognition as a food destination in very famous media, having established an official website for visitors where they could upload their impressions (Nelson, 2016), and in Malaysia, by promoting annual events with 151 traditional national foods with promotional material emphasising the unique characteristics of Malaysian cuisine with promotional words and texts such as 'close-up meal', 'creating desire' and 'sensory appeal' (Jalis et al., 2014). On the other hand, non-successful marketing of Istanbul city as a culinary destination as indicated by Okumus and Cetin (2018), after conducting a content analysis, since food was not properly marketed as a major characteristic of the city, while in the survey conducted in Australia, a lack of consensus between promotional images of the Tourism Department of Australia and the food industry stakeholders had, as a consequence, the adopted marketing strategies to be ineffective as well (Lai et al., 2018). Concerning halal food, Japan, Thailand, and South Korea have also marketed their countries effectively as halal tourist destinations for Muslim tourists by promoting halal cuisines, food culture, restaurants, and services; on the contrary, this was not quite successfully done in China, since religion was promoted as an ethnic topic in its culinary tourism policies (Yousaf and Xiucheng, 2018). Moreover, in South Korea, a psychometric analytical approach was established to understand halal-friendly performance quality and the plan to maintain and control quality characteristics for the development of halal tourism in a non-Organization of Islamic Cooperation destination (Al-Ansi and Han, 2019).

The latest social media technology improvements could be a handy tool for the promotion of food tourism and the economic development of an area by discoursing privileged middle-class cultural symbols via official promotion (Jong and Varley, 2017) and by the creation of an official governmental Instagram account advertising the unique local food characteristics ( $\mathrm{Yu}$ and Sun, 2019). That new trend of food-Instagramming could be beneficial for tourists since they could share dining experiences, attitudes, and 
impressions from a destination that could affect the travel behaviour of their followers (Wong et al., 2019). Multisensory virtual experiences were also used as a technological improvement to promote wine tourism in Porto (Martins et al., 2017). Concerning the use of technology to promote food tourism in food services, marketers could create promotions, coupons, and advertisements for online apps and social media sites to match these needs. Apps and social media were used from all the segments of high-frequency wine consumers. Specifically, low spenders used wine apps mainly to download coupons in grocery stores; on the other hand, moderate and high spenders used social media mainly for information and communication with friends and relatives (Thach and Olsen, 2015).

\section{Discussion}

By attaining a holistic approach to food tourism management, history, culture, authenticity of a local food product, food service establishment, and food destination could be better developed and promoted, tourists would be more motivated to search for local food, to learn about its special attributes, be actively involved in gastronomic activities, acquiring unique and memorable experiences, be better able to define and improve their attitude, beliefs, emotions, and desires, and increase the level of satisfaction towards local food/related activities that will positively affect the intentions to purchase and recommend a food product, revisit and recommend a food service establishment/destination.

A complex multidimensional conceptual model was also developed for food tourism management under a holistic approach taking into account the demand and supply perspectives, as well as broad categories of food tourism in order to better understand the decision-making system concerning behavioural outcomes.

From the analysis of the conceptual framework, it is clear that the results of different articles concerning the same topic may differ. The main reasons, among others, refer to the different profile (demographic characteristics), personal values and interests of tourists such as the desire for knowledge, motives, active involvement, personal beliefs (attitudes, subjective norms, perceived behavioural control), perceptions, emotions, desires, experiences, and satisfaction; the existence of a well-organised stakeholders' network and their initiatives concerning marketing activities to effectively promote the image and the brand of the specific and various characteristics of a food product, food service establishments and food destination (city, region, country), that are linked with different and unique characteristics of culture, history and authenticity. Moreover, some technical characteristics such as the sample size, the research methodology, and the period of research may play a significant role in the differentiation and interpretation of the results. Thus, all the above characteristics and factors should be carefully considered when tourists' behavioural intentions are investigated.

The main trends derived from the paper are consistent with the latest findings of the World Food Travel Association (2020) via '2020 Food Travel Monitor'. Travellers' food neophilia differs between genders and generational cohorts (Okumus et al., 2021). They would like to take up alternative forms of food tourism (Luoh et al., 2020; Arroyo et al., 2021; Moshin et al., 2020), to taste street food (Jeaheng and Han, 2020), to visit new food establishments other than mainstream restaurants (Kim et al., 2020; Lugosi et al., 2020), 
to take part in experience co-creation practices (Rachao et al., 2021; Lugosi et al., 2020), to strengthen family bonds by eating all the members together and promoting their experience by word-of-mouth to their friends and relatives (Lai, 2020) or/and by uploading photos and comments on social media (Wong et al., 2019). Memorable experiential food experiences could enhance tourists' intentions to buy local food products, revisit food establishment and gastronomic destination, leading to regional economic and socio-cultural development (Wondirad et al., 2021).

\section{Implications}

This paper aimed to shed light on the food tourism approaches and management issues, providing several implications.

By defining local food and its preference against conventional food; distinguishing the terms 'food tourism', 'gastronomic tourism', 'culinary tourism' and 'cuisine'; linking food tourism with different forms of special interest tourism connected with food such as slow food tourism, halal food tourism, street food tourism, gourmet tourism, ethnic food tourism, traditional food tourism, salt tourism, olive oil tourism, beer tourism, wine tourism, agrotourism and green tourism; distinguishing the food service establishments in various categories, such as restaurants, Michelin restaurants, luxury restaurants, 4 and 5 star hotel restaurants, ethnic restaurants, green restaurants, authentic restaurants, hot pot restaurants, pop-up restaurants, upscale restaurants, fast food restaurants, hotels, grocerants, groceries, premium food markets, farmers' markets, food tourism factories, food trucks, breweries, wineries, cellar door tasting rooms, olive oil companies, halal food establishments, universities and festivals; and finally, comprehending food tourism destinations such as historical cities, districts, popular food and wine regions, villages and 'gastronomic' countries; the outcomes of this paper could act as a guideline for the relative stakeholders, consultants, practitioners, managers, researchers and academicians who are involved in food tourism to better understand the concepts and the interlinkages of the main factors of each category that influence tourists' behavioural outcomes, which would enable them to design, follow and implement the most appropriate strategy.

The positive effect of the increase in tourists' intentions could lead to a rise in the sales and exports of the local products, an increase in investments, and an increase in the number of tourists in a destination, by enhancing the food product, foodservice and destination image, which could lead to the development of the area.

Food tourism could contribute quite efficiently to socio-economic development by promoting the cultural and historical attributes of a destination through a holistic approach by considering tourists' and stakeholders' views as derived from the referred conceptual framework, which is in line with Kumar (2019) outcomes. Taking into account the opinions of local stakeholders and consumers, the policymakers should promote alternative and local food systems together with conventional systems in the development of rural areas as O'Neill (2014) suggested. A sustainable model of entrepreneurial initiative that reconstructs the territory in such a way that it could be beneficial not only for tourists but also for the local stakeholders and the residents, by respecting the environment, encouraging local youth employment, tightening social relations, maintaining natural resources and promoting cultural heritage could also be promoted based on Sanità (2016) analysis. 
Strengthening inter-sectoral linkages between the agriculture sector and accommodation properties will benefit the corresponding stakeholders and encourage youth employment, which could lead to sustainable tourism development (Nguyen et al., 2019). Moreover, the relationships among food producers and restaurant owners, attitudes (preferences, past experience), behaviours towards sourcing (order processing time), unique product characteristics, and promotional materials play significant roles in the WTP for local food as inputs among the value chain of restaurants as noticed by Sharma et al. (2014), whereas the significance of personal relationships and trust among farmers, producers (sellers) and food distributors, food services (buyers) could contribute to the sustainability of food systems and the maintenance of competitive advantage at the same time as mentioned by Roy et al. (2017). Furthermore, the active involvement of local residents with tourists, offering experiential activities by the creation of food clusters with the appearance of strong leadership, could lead to the sustainable development of an area emphasising the unique economic, cultural, and environmental characteristics of a place which is much in line with Lee et al. (2015a) outcomes.

\section{Conclusions}

Food tourism is developing with a very fast growth rate in recent years. There are many travellers, foodies, food hunters, or gastronomes whose primary motivation is to visit a destination to taste the local agricultural products and/or take up related activities, learn, and explore local culture, history, and authenticity, acquiring memorable experiential experiences. Although there is no consensus on the definition of 'local' concerning the production site, this does not seem to be so important since tourists are interested mainly in the quality characteristics of the food product. Therefore, cuisine and culinary tourism have been replaced by the term's gastronomy tourism and food tourism. It is noticed that the first two terms are usually used to describe ethnic food.

Moreover, in this paper, we tried to pinpoint current trends by categorising and analysing the main approaches that are crucial in food tourism research and by conceptualising a framework with those approaches that affect food products, food service establishments and destination characteristics from both tourists' and stakeholders' perspective, which in turn affect directly or indirectly the decision making on behavioural intentions as to whether to purchase and/or recommend a food product and to revisit and/or recommend a food service establishment and/or a food destination.

To the best of our knowledge, this is the first study that combines an analysis of food tourism approaches in broad categories such as motives, culture, history, authenticity, marketing, and experiences and a conceptual food tourism management framework that takes into account the various characteristics from food product, food service and destination in a holistic perspective. Interlinkages among them and other subcategories together with theoretical and managerial implications were pinpointed, discussed, and analysed.

We are looking forward to the outcomes of this paper, substantially contribute to the evolution of food tourism management research. Furthermore, it is proposed, for more solid outcomes, that future researches on food tourism should focus more on implementing more researches from the supply side in foodservice establishments which are not so common, in towns and countries that are not adequately analysed in the 
literature so far, in sustainability issues incorporating all three dimensions at the same time, namely economic, socio-cultural and environmental aspects, whereas there is a need for a holistic approach that takes into account both tourists' and stakeholders' perspective, in order to better understand all the primary factors and relations that affect or could affect positively or negatively, directly or indirectly, tourists' behavioural outcomes.

\section{References}

Adongo, C.A., Anuga, S.W. and Dayour, F. (2015) 'Will they tell others to taste? International tourists' experience of Ghanaian cuisines', Tourism Management Perspectives, Vol. 15, pp.57-64.

Afonso, C., Silva, G.M., Gonçalves, H.M. and Duarte, M. (2018) 'The role of motivations and involvement in wine tourists' intention to return: SEM and fsQCA findings', Journal of Business Research, Vol. 89, pp.313-321.

Al-Ansi, A. and Han, H. (2019) 'Role of halal-friendly destination performances, value, satisfaction, and trust in generating destination image and loyalty', Journal of Destination Marketing \& Management, Vol. 13, pp.51-60.

Alderighi, M., Bianchi, C. and Lorenzini, E. (2016) 'The impact of local food specialities on the decision to (re)visit a tourist destination: market-expanding or business-stealing?', Tourism Management, Vol. 57, pp.323-333.

Alebaki, M., Menexes, G. and Koutsouris, A. (2015) 'Developing a multidimensional framework for wine tourist behavior: evidence from Greece', Wine Economics and Policy, Vol. 4, No. 2, pp.98-109.

Arroyo, C.G., Knollenberg, W. and Barbieri, C. (2021) 'Inputs and outputs of craft beverage tourism: the destination resources acceleration framework', Annals of Tourism Research, Vol. 86 [online] https://doi.org/10.1016/j.annals.2020.103102.

Balderas-Cejudo, A., Patterson, I. and Leeson, G.W. (2019) 'Senior foodies: a developing niche market in gastronomic tourism', International Journal of Gastronomy and Food Science, Vol. 16, p.100152.

Barlagne, C., Bazoche, P., Thomas, A., Ozier-Lafontaine, H., Causeret, F. and Blazy, J.M. (2015) 'Promoting local foods in small island states: the role of information policies', Food Policy, Vol. 57, pp.62-72.

Basri, N.A.H., Ahmad, R., Anuar, F.I. and Ismail, K.A. (2016) 'Effect of word of mouth communication on consumer purchase decision: Malay upscale restaurant', Procedia - Social and Behavioral Sciences, Vol. 222, pp.324-331.

Batat, W., Peter, P.C., Moscato, E.M., Castro, I.A., Chan, S., Chugani, S. and Muldrow, A. (2019) 'The experiential pleasure of food: a savoring journey to food well-being', Journal of Business Research, Vol. 100, pp.392-399.

Bencivenga, A., Vollaro, P.D., Forte, F., Giampietro, A.M. and Percoco, P.A. (2016) 'Food and wine tourism in Basilicata', Agriculture and Agricultural Science Procedia, Vol. 8, pp.176-185.

Berbel-Pineda, J.M., Palacios-Florencio, B., Ramírez-Hurtado, J.M. and Santos-Roldán, L. (2019) 'Gastronomic experience as a factor of motivation in the tourist movements', International Journal of Gastronomy and Food Science, Vol. 18, No. 3, p.100171.

Berg, N. and Preston, K.L. (2017) 'Willingness to pay for local food?: Consumer preferences and shopping behavior at Otago farmers market', Transportation Research Part A, Vol. 103, pp.343-361.

Björk, P. and Kauppinen-Räisänen, H. (2019) 'Destination foodscape: a stage for travelers' food experience', Tourism Management, April, Vol. 71, pp.466-475. 
Bondzi-Simpson, A. and Ayeh, J.K. (2017) 'Serving indigenous dishes in hotels: an inquiry into the conative response of menu decision makers', International Journal of Hospitality Management, Vol. 67, pp.115-124.

Bryła, P. (2015) 'The role of appeals to tradition in origin food marketing. A survey among Polish consumers', Appetite, Vol. 91, pp.302-310.

Byrd, E.T., Canziani, B., Hsieh, Y-C. Debbage, K. and Sonmez, S. (2016) 'Wine tourism: motivating visitors through core and supplementary services', Tourism Management, Vol. 52, pp.19-29.

Campbell, J., DiPietro, R.B. and Remar, D. (2014) 'Local foods in a university setting: price consciousness, product involvement, price/quality inference and consumer's willingness-to-pay', International Journal of Hospitality Management, Vol. 42, pp.39-49.

Casini, L., Contini, C., Romano, C. and Scozzafava, G. (2016) 'New trends in food choice: what impact on sustainability of rural areas?', Agriculture and Agricultural Science Procedia, Vol. 8, pp.141-147.

Chang, R.C.Y. and Mak, A.H.N. (2018) 'Understanding gastronomic image from tourists' perspective: a repertory grid approach', Tourism Management, Vol. 68, pp.89-100.

Chatzopoulou, E., Gorton, M. and Kuznesof, S. (2019) 'Understanding authentication processes and the role of conventions: a consideration of Greek ethnic restaurants', Annals of Tourism Research, Vol. 77, pp.128-140.

Chavarria, L.C.T. and Phakdee-auksorn, P. (2017) 'Understanding international tourists' attitudes towards street food in Phuket, Thailand', Tourism Management Perspectives, Vol. 21, pp.66-73.

Chen, A. and Peng, N. (2018) 'Examining consumers' intentions to dine at luxury restaurants while traveling', International Journal of Hospitality Management, Vol. 71, pp.59-67.

Chen, A., Peng, N. and Hung, K-P. (2016) 'Chef image's influence on tourists' dining experiences', Annals of Tourism Research, Vol. 56, pp.128-163.

Chen, H-B., Yeh, S-S. and Huan, T-C. (2014) 'Nostalgic emotion, experiential value, brand image, and consumption intentions of customers of nostalgic-themed restaurants', Journal of Business Research, Vol. 67, No. 3, pp.354-360.

Chien, S-H., Wu, J-J. and Huang, C-Y. (2018) "WWe made, we trust": coproduction and image congruence in the food-tourism factories', Asia Pacific Management Review, Vol. 23, No. 4, pp.310-317.

Choe, J.Y. and Kim, S. (2018) 'Effects of tourists' local food consumption value on attitude, food destination image, and behavioral intention', International Journal of Hospitality Management, Vol. 71, pp.1-10.

Choe, J.Y. and Kim, S. (2019) 'Development and validation of a multidimensional tourist's local food consumption value (TLFCV) scale', International Journal of Hospitality Management, Vol. 77, pp.245-259.

Cruz, F.G.F., Tito, J.C., Pérez-Gálvez, J.C. and Medina-Viruel, M.J. (2019) 'Gastronomic experiences of foreign tourists in developing countries. The case in the city of Oruro (Bolivia)', Heliyon, Vol. 5, No. 7, pp.1-8.

Di Matteo, D. and Cavuta, G. (2016) 'Enogastronomic tourism: can it mitigate the intangibility of the destination? Streetfood as a new business model for the management of tourist regions', Procedia Economics and Finance, Vol. 39, pp.347-356.

Di Vita, G., Caracciolo, F., Brun, F. and D'Amico, M. (2019) 'Picking out a wine: consumer motivation behind different quality wines choice', Wine Economics and Policy, Vol. 8, No. 1, pp.16-27.

DiPietro, R.B., Levitt, J.A., Taylor, S. and Nierop, T. (2019) 'First-time and repeat tourists' perceptions of authentic Aruban restaurants: an importance-performance competitor analysis', Journal of Destination Marketing \& Management, Vol. 14, No. 2, p.100366. 
Douglas N., Douglas, N. and Derrett, R. (2001) Special Interest Tourism: Context and Cases, John Wiley and Sons, Brisbane and Melbourne.

Ellis, A., Park, E., Kim, S. and Yeoman, I. (2018) 'What is food tourism?', Tourism Management, Vol. 68, pp.250-263.

Eustice, C., McCole, D. and Rutty, M. (2019) 'The impact of different product messages on wine tourists' willingness to pay: a non-hypothetical experiment', Tourism Management, Vol. 72, No. 529, pp.242-248.

Fernandes, T. and Cruz, M. (2016) 'Dimensions and outcomes of experience quality in tourism: the case of Port wine cellars', Journal of Retailing and Consumer Services, Vol. 31, No. 2, pp.371-379.

Festa, G., Cuomo, M.T., Metallo, G. and Festa, A. (2016) 'The (r)evolution of wine marketing mix: from the 4Ps to the 4Es', Journal of Business Research, Vol. 69, No. 5, pp.1550-1555.

Filimonau, V. and Krivcova, M. (2017) 'Restaurant menu design and more responsible consumer food choice: an exploratory study of managerial perceptions', Journal of Cleaner Production, Vol. 143, pp.516-527.

Folgado-Fernandez, J.A., Campon-Cerro, A.M. and Hernandez-Mogollon, J.M. (2019) 'Potential of olive oil tourism in promoting local quality food products: a case study of the region of Extremadura, Spain', Heliyon, Vol. 5, No. 10, p.e02653.

Francioni, B., Vissak, T. and Musso, F. (2017) 'Small Italian wine producers' internationalization: the role of network relationships in the emergence of late starters', International Business Review, Vol. 26, No. 1, pp.12-22.

Garibaldi, R., Stone, M.J., Wolf, E. and Pozzi, A. (2017) 'Wine travel in the United States: a profile of wine travellers and wine tours', Tourism Management Perspectives, Vol. 23, pp.53-57.

Georgica, G. (2015) 'The tourist's perception about slow travel - a Romanian perspective', Procedia Economics and Finance, Vol. 23, pp.1596-1601.

Gómez, M., González-Díaz, B. and Molina, A. (2015a) 'Priority maps at wine tourism destinations: an empirical approach in five Spanish wine regions', Journal of Destination Marketing \& Management, Vol. 4, No. 4, pp.258-267.

Gómez, M., Lopez, C. and Molina, A. (2015b) 'A model of tourism destination brand equity: the case of wine tourism destinations in Spain', Tourism Management, Vol. 51, pp.210-222.

Hall, C.M. and Sharples, L. (2003) 'The consumption of experiences or the experience of consumption? An introduction to the tourism of taste', in Hall, C.M., Sharples, L., Mitchell, R., Macionis, N. and Cambourne, B. (Eds.): Food Tourism Around the World: Development, Management and Markets, pp.1-24, Butterworth-Heinemann, Oxford.

Harrington, R.J., Freyberg, B., Ottenbacher, M.C. and Schmidt, L. (2017) 'The different effects of dis-satisfier, satisfier and delighter attributes: implications for Oktoberfest and beer festivals', Tourism Management Perspectives, Vol. 24, pp.166-176.

Hendijani, R.B. and Chern, B.H. (2014) 'Food hunting - a search of the past and dream of the future', Procedia - Social and Behavioral Sciences, Vol. 144, pp.218-222.

Horng, J.S. and Tsai, C.T.S. (2012) 'Culinary tourism strategic development: an Asia-Pacific perspective', International Journal of Tourism Research, Vol. 14, No. 1, pp.40-55.

Huang, J. (2017) 'The dining experience of Beijing roast duck: a comparative study of the Chinese and English online consumer reviews', International Journal of Hospitality Management, Vol. 66, pp.117-129.

Ismail, T.A.T., Muhammad, R., Yusoff, N.M. and Shariff, M.S.M. (2016) 'The myth and reality of hotel brand and food quality: the case of hotel restaurants in Malaysia', Procedia-Social and Behavioral Sciences, Vol. 222, pp.382-389.

Jalis, M.H., Che, D. and Markwell, K. (2014) 'Utilising local cuisine to market Malaysia as a tourist destination', Procedia - Social and Behavioral Sciences, Vol. 144, pp.102-110.

Jeaheng, Y. and Han, H. (2020) 'Thai street food in the fast growing global food tourism industry: preference and behaviors of food tourists', Journal of Hospitality and Tourism Management, Vol. 45, pp.641-655. 
Ji, M., Wong, I.A., Eves, A. and Scarles, C. (2016) 'Food-related personality traits and the moderating role of novelty-seeking in food satisfaction and travel outcomes', Tourism Management, Vol. 57, pp.387-396.

Jia, S. (2020) 'Motivation and satisfaction of Chinese and U.S. tourists in restaurants: a cross-cultural text mining of online reviews', Tourism Management, Vol. 78, p.104071.

Jong, A. and Varley, P. (2017) 'Food tourism policy: deconstructing boundaries of taste and class', Tourism Management, Vol. 60, pp.212-222.

Kiatkawsin, K. and Han, H. (2019) 'What drives customers' willingness to pay price premiums for luxury gastronomic experiences at Michelin-starred restaurants?', International Journal of Hospitality Management, Vol. 82, pp.209-219.

Kim, J-H. (2014) 'The antecedents of memorable tourism experiences: the development of a scale to measure the destination attributes associated with memorable experiences', Tourism Management, Vol. 44, pp.34-45.

Kim, J-H., Youn, H. and Rao, Y. (2017) 'Customer responses to food-related attributes in ethnic restaurants', International Journal of Hospitality Management, Vol. 61, pp.129-139.

Kim, S., Ham, S., Moon, H., Chua, B-L. and Han, H. (2019a) 'Experience, brand prestige, perceived value (functional, hedonic, social, and financial), and loyalty among GROCERANT customers', International Journal of Hospitality Management, Vol. 77, pp.169-177.

Kim, S., Lee, S.K., Lee, D., Jeong, J. and Moon, J. (2019b) 'The effect of agritourism experience on consumers' future food purchase patterns', Tourism Management, Vol. 70, No. 2, pp.144-152.

Kim, S., Park, E. and Lamb, D. (2019c) 'Extraordinary or ordinary? Food tourism motivations of Japanese domestic noodle tourists', Tourism Management Perspectives, Vol. 29, pp.176-186.

Kim, W-H., Cho, J-L. and Kim, K-S. (2019d) 'The relationships of wine promotion, customer satisfaction, and behavioral intention: the moderating roles of customers' gender and age', Journal of Hospitality and Tourism Management, Vol. 39, No. 1, pp.212-218.

Kim, S., Park, E. and Xu, M. (2020) 'Beyond the authentic taste: the tourist experience at a food museum restaurant', Tourism Management Perspectives, Vol. 36 [online] https://doi.org/ 10.1016/j.tmp.2020.100749.

Kohsaka, R. (2017) 'The myth of washoku: a twisted discourse on the 'uniqueness' of national food heritages', Journal of Ethnic Foods, Vol. 4, No. 2, pp.66-71.

Kohsaka, R., Matsuoka, H. and Uchiyama, Y. (2016) 'Capturing the relationships between local foods and residents: a case in the Noto region, Japan', Journal of Ethnic Foods, Vol. 3, No. 2, pp.86-92.

Kraftchick, J.F., Byrd, E.T., Canziani, B. and Gladwell, N.J. (2014) 'Understanding beer tourist motivation', Tourism Management Perspectives, Vol. 12, No. 2, pp.41-47.

Kumar, G.M.K. (2019) 'Gastronomic tourism - a way of supplementing tourism in the Andaman \& Nicobar Islands', International Journal of Gastronomy and Food Science, Vol. 16, No. 1, p.100139.

Lai, I.K.W. (2020) 'An examination of satisfaction on word of mouth regarding Portuguese foods in Macau: applying the concept of integrated satisfaction', Journal of Hospitality and Tourism Management, Vol. 43 [online] https://doi.org/10.1016/j.jhtm.2020.02.011.

Lai, M.Y., Khoo-Lattimore, C. and Wang, Y. (2018) 'A perception gap investigation into food and cuisine image attributes for destination branding from the host perspective: the case of Australia', Tourism Management, Vol. 69, pp.579-595.

Lang, M. and Lemmerer, A. (2019) 'How and why restaurant patrons value locally sourced foods and ingredients', International Journal of Hospitality Management, Vol. 77, pp.76-88.

Lau, C. and Li, Y. (2019) 'Analyzing the effects of an urban food festival: a place theory approach', Annals of Tourism Research, Vol. 74, pp.43-55. 
Le, T.H., Arcodia, C., Novais, M.A. and Kralj, A. (2019) 'What we know and do not know about authenticity in dining experiences: a systematic literature review', Tourism Management, Vol. 74, No. 1, pp.258-275.

Lee, A.H.J., Wall, G. and Kovacs, J.F. (2015a) 'Creative food clusters and rural development through place branding: culinary tourism initiatives in Stratford and Muskoka, Ontario, Canada', Journal of Rural Studies, Vol. 39, pp.133-144.

Lee, K-H., Packer, J. and Scott, N. (2015b) 'Travel lifestyle preferences and destination activity choices of slow food members and non-members', Tourism Management, Vol. 46, pp.1-10.

Lee, H., Jang, Y., Kim, Y., Choi, H-M. and Ham, S. (2019a) 'Consumers' prestige-seeking behavior in premium food markets: application of the theory of the leisure class', International Journal of Hospitality Management, Vol. 77, pp.260-269.

Lee, R., Lockshin, L., Cohen, J. and Corsi, A. (2019b) 'A latent growth model of destination image's halo effect', Annals of Tourism Research, Vol. 79, p.102767.

Lee, K-H., Scott, N. and Packer, J. (2014) 'Habitus and food lifestyle: in-destination activity participation of slow food members', Annals of Tourism Research, Vol. 48, pp.207-220.

Lee, T.H., Chao, W.H. and Lin, H-Y. (2018) 'Cultural inheritance of Hakka cuisine: a perspective from tourists' experiences', Journal of Destination Marketing \& Management, Vol. 7, pp.101-111.

Li, J., Deng, J. and Pierskalla, C. (2018) 'Impact of attendees' motivation and past experience on their attitudes toward the National Cherry Blossom Festival in Washington, D.C.', Urban Forestry \& Urban Greening, Vol. 36, No. 3, pp.57-67.

Lin, J., Cui, Q., Marin, J. and Xu, H. (2019) 'Distinction and omnivorousness in tourists' food consumption', International Journal of Hospitality Management, Vol. 83, pp.95-102.

Lin, L. and Mao, P-C. (2015) 'Food for memories and culture - a content analysis study of food specialties and souvenirs', Journal of Hospitality and Tourism Management, Vol. 22, pp.19-29.

Line, N.D., Hanks, L. and Zhang, L. (2016) 'Sustainability communication: the effect of message construals on consumers' attitudes towards green restaurants', International Journal of Hospitality Management, Vol. 57, pp.143-151.

Lita, R.P., Surya, S., Ma'ruf, M. and Syahrul, L. (2014) 'Green attitude and behavior of local tourists towards hotels and restaurants in West Sumatra, Indonesia', Procedia Environmental Sciences, Vol. 20, pp.261-270.

Littaye, A.Z. (2016) 'The multifunctionality of heritage food: the example of pinole, a Mexican sweet', Geoforum, Vol. 76, pp.11-19.

Liu, S.Q. and Mattila, A.S. (2015) 'Ethnic dining: need to belong, need to be unique, and menu offering', International Journal of Hospitality Management, Vol. 49, pp.1-7.

López-Guzmán, T., Di-Clemente, E. and Hernández-Mogollón, J.M. (2014a) 'Culinary tourists in the Spanish region of Extremadura, Spain', Wine Economics and Policy, Vol. 3, No. 1, pp.10-18.

López-Guzmán, T., Vieira-Rodríguez, A. and Rodríguez-García, J. (2014b) 'Profile and motivations of European tourists on the Sherry wine route of Spain', Tourism Management Perspectives, Vol. 11, pp.63-68.

Lourenço-Gomes, L., Pinto, L.M.C. and Rebelo, J. (2015) 'Wine and cultural heritage. The experience of the Alto Douro Wine Region', Wine Economics and Policy, Vol. 4, No. 2, pp.78-87.

Lu, L. and Chi, C.G-Q. (2018) 'Examining diners' decision-making of local food purchase: the role of menu stimuli and involvement', International Journal of Hospitality Management, Vol. 69, pp.113-123.

Lugosi, P., Robinson, R.N.S., Walters, G. and Donaghy, S. (2020) 'Managing experience co-creation practices: direct and indirect inducement in pop-up food tourism events', Tourism Management Perspectives, Vol. 35 [online] https://doi.org/10.1016/j.tmp.2020.100702. 
Luoh, H-F., Tsaur, S-H. and Lo, P-C. (2020) 'Cooking for fun: the sources of fun in cooking learning tourism', Journal of Destination Marketing and Management, Vol. 17 [online] https://doi.org/10.1016/j.jdmm.2020.100442.

Madaleno, A., Eusebio, C. and Varum, C. (2017) 'Purchase of local food products during trips by international visitors', International Journal of Tourism Research [online] https://doi.org/ $10.1002 /$ jtr.2167.

Marchini, A., Riganelli, C., Diotallevi, F. and Paffarini, C. (2014) 'Factors of collective reputation of the Italian PDO wines: an analysis on central Italy', Wine Economics and Policy, Vol. 3, No. 16, pp.127-137.

Martins, J., Gonçalves, R., Branco, F., Barbosa, L., Melo, M. and Bessa, M. (2017) 'A multisensory virtual experience model for thematic tourism: a Port wine tourism application proposal', Journal of Destination Marketing \& Management, Vol. 6, No. 2, pp.103-109.

Matson-Barkat, S. and Robert-Demontrond, P. (2018) 'Who's on the tourists' menu? Exploring the social significance of restaurant experiences for tourists', Tourism Management, Vol. 69, pp.566-578.

McNamara, N. and Cassidy, F. (2015) 'Wine tasting: to charge or not to charge?', International Journal of Hospitality Management, Vol. 49, pp.8-16.

Meneguel, C.R.A., Mundet, L. and Aulet, S. (2019) 'The role of a high-quality restaurant in stimulating the creation and development of gastronomy tourism', International Journal of Hospitality Management, Vol. 83, pp.220-228.

Meng, B. and Choi, K. (2016) 'The role of authenticity in forming slow tourists' intentions: developing an extended model of goal-directed behavior', Tourism Management, Vol. 57, pp.397-410.

Meyerding, S.G.H., Trajer, N. and Lehberger, M. (2019) 'What is local food? The case of consumer preferences for local food labeling of tomatoes in Germany', Journal of Cleaner Production, Vol. 207, No. 10, pp.30-43.

Millán-Vazquez de la Torre, M.G., Arjona-Fuentes, J.M. and Amador-Hidalgo, L. (2017) 'Olive oil tourism: promoting rural development in Andalusia (Spain)', Tourism Management Perspectives, Vol. 21, No. 1, pp.100-108.

Mohammed, J., Seleshi, S., Nega, F. and Lee, M. (2016) 'Revisit to Ethiopian traditional barley-based food', Journal of Ethnic Foods, Vol. 3, No. 2, pp.135-141.

Moshin, A., Brochado, A. and Rodrigues, H. (2020) 'Halal tourism is traveling fast: community perceptions and implications', Journal of Destination Marketing and Management, Vol. 18 [online] https://doi.org/10.1016/j.jdmm.2020.100503.

Muhammad, R., Ramli, N., Yusoff, N.M. and Ismail, T.A.T. (2016) 'Are visitors satisfied and intend to revisit Rumah Terbuka Aidilfitri?: Malaysian community in Perak', Procedia Social and Behavioral Sciences, Vol. 222, pp.351-357.

Musso, F. and Francioni, B. (2015) 'Agri-food clusters, wine tourism and foreign markets. The role of local networks for SME's internationalization', Procedia Economics and Finance, Vol. 27, pp.334-343.

Mynttinen, S., Logren, J., Sarkka-Tirkkonen, M. and Rautiainen, T. (2015) 'Perceptions of food and its locality among Russian tourists in the South Savo region of Finland', Tourism Management, Vol. 48, pp.455-466.

Nelson, V. (2016) 'Food and image on the official visitor site of Houston, Texas', Journal of Destination Marketing \& Management, Vol. 5, No. 2, pp.133-140.

Neuninger, R., Mather, D. and Duncan, T. (2017) 'Consumer's scepticism of wine awards: a study of consumers' use of wine awards', Journal of Retailing and Consumer Services, Vol. 35, pp.98-105.

$\mathrm{Ng}, \mathrm{C.Y}$. and Karim, S.A. (2016) 'Historical and contemporary perspectives of the Nyonya food culture in Malaysia', Journal of Ethnic Foods, Vol. 3, No. 2, pp.93-106. 
Nguyen, T.Q.T., Young, T., Johnson, P. and Wearing, S. (2019) 'Conceptualising networks in sustainable tourism development', Tourism Management Perspectives, Vol. 32, No. 5, p.100575.

O'Neill, K.J. (2014) 'Situating the 'alternative' within the 'conventional' - local food experiences from the East Riding of Yorkshire, UK', Journal of Rural Studies, Vol. 35, No. 1, pp.112-122.

Oktay, S. and Sadikoglu, S. (2018a) 'Gastronomic cultural impacts of Russian, Azerbaijani and Iranian cuisines', International Journal of Gastronomy and Food Science, Vol. 12, pp.6-13.

Oktay, S. and Sadikoglu, S. (2018b) 'The gastronomic cultures' impact on the African cuisine', Journal of Ethnic Foods, Vol. 5, No. 2, pp.140-146.

Okumus B. and Cetin, G. (2018) 'Marketing Istanbul as a culinary destination', Journal of Destination Marketing \& Management, Vol. 9, No. 5, pp.340-346.

Okumus, B., Dedeoglu, B.B. and Shi, F. (2021) 'Gender and generation as antecedents of food neophobia and food neophilia', Tourism Management Perspectives, Vol. 37 [online] https://doi.org/10.1016/j.tmp.2020.100773.

Omar, S.R., Karim, S.A., Bakar, A.Z.A. and Omar, S.N. (2015) 'Safeguarding Malaysian heritage food (MHF): the impact of Malaysian food culture and tourists' food culture involvement on intentional loyalty', Procedia - Social and Behavioral Sciences, Vol. 172, pp.611-618.

Organ, K., Koenig-Lewis, N., Palmer, A. and Probert, J. (2015) 'Festivals as agents for behaviour change: a study of food festival engagement and subsequent food choices', Tourism Management, Vol. 48, pp.84-99.

Osman, H., Johns, N. and Lugosi, P. (2014) 'Commercial hospitality in destination experiences: McDonald's and tourists' consumption of space', Tourism Management, Vol. 42, pp.238-247.

Özdemir, B. and Seyitoğlu, F. (2017) 'A conceptual study of gastronomical quests of tourists: authenticity or safety and comfort?', Tourism Management Perspectives, Vol. 23, pp.1-7.

Park, J-Y., Bufquin, D. and Back, R.M. (2019) 'When do they become satiated? An examination of the relationships among winery tourists' satisfaction, repeat visits and revisit intentions', Journal of Destination Marketing \& Management, Vol. 11, pp.231-239.

Peng, N., Chen, A. and Hung, K-P. (2017) 'The effects of teppanyaki restaurant stimuli on diners' emotions and loyalty', International Journal of Hospitality Management, Vol. 60, pp.1-12.

Pérez-Gálvez, J.C., Granda, M.J., López-Guzmán, T. and Coronel, J.R. (2017a) 'Local gastronomy, culture and tourism sustainable cities: the behavior of the American tourist', Sustainable Cities \& Society, Vol. 32, pp.604-612.

Pérez-Gálvez, J.C., López-Guzmán, T., Buiza, F.C. and Medina-Viruel, M.J. (2017b) 'Gastronomy as an element of attraction in a tourist destination: the case of Lima, Peru', Journal of Ethnic Foods, Vol. 4, No. 4, pp.254-261.

Pillai, K.G., Liang, Y-S., Thwaites, D. and Sharma, P. (2019) 'Regulatory focus, nutrition involvement, and nutrition knowledge', Appetite, Vol. 137, No. 1, pp.267-273.

Privitera, D. and Nesci, F.S (2015) 'Globalization vs. local. The role of street food in the urban food system', Procedia Economics and Finance, Vol. 22, No. 22, pp.716-722.

Promsivapallop, P. and Kannaovakun, P. (2019) 'Destination food image dimensions and their effects on food preference and consumption', Journal of Destination Marketing \& Management, Vol. 11, pp.89-100.

Pulido-Fernandez, J.I., Casado-Montilla, J. and Carrillo-Hidalgo, I. (2019) 'Introducing olive-oil tourism as a special interest tourism', Heliyon, Vol. 5, No. 12, p.e02975.

Quintal, V.A., Thomas, B. and Phau, I. (2015) 'Incorporating the winescape into the theory of planned behaviour: examining 'new world' wineries', Tourism Management, Vol. 46, pp.596-609.

Rabbiosi, C. (2016) 'Place branding performances in tourist local food shops', Annals of Tourism Research, Vol. 60, pp.154-168. 
Rachao, S.A.S., Breda, Z.J., Fernandes, C.O. and Jonkes, V.N.P.M. (2021) 'Drivers of experience co-creation in food-and-wine tourism: an exploratory quantitative analysis', Tourism Management Perspectives, Vol. 37 [online] https://doi.org/10.1016/j.tmp.2020.100783.

Rahman, I. and Reynolds, D. (2015) 'Wine: intrinsic attributes and consumers' drinking frequency, experience, and involvement', International Journal of Hospitality Management, Vol. 44, pp.1-11.

Rana, J. and Paul, J. (2017) 'Consumer behavior and purchase intention for organic food: a review and research agenda', Journal of Retailing and Consumer Services, Vol. 38, pp.157-165.

Renna, M., Rinaldi, V.A. and Gonnella, M. (2015) 'The Mediterranean diet between traditional foods and human health: the culinary example of Puglia (Southern Italy)', International Journal of Gastronomy and Food Science, Vol. 2, No. 2, pp.63-71.

Richards, G. (2002) 'Gastronomy: an essential ingredient in tourism production and production', in Hjalager, A.M. and Richards, G. (Eds.): Tourism and Gastronomy, pp.3-20, Routledge, London.

Roy, H., Hall, C.M. and Ballantine, P.W. (2017) 'Trust in local food networks: the role of trust among tourism stakeholders and their impacts in purchasing decisions', Journal of Destination Marketing \& Management, Vol. 6, No. 4, pp.309-317.

Samori, Z., Salleh, N.Z.M. and Khalid, M.M. (2016) 'Current trends on halal tourism: cases on selected Asian countries', Tourism Management Perspectives, Vol. 19, Part B, pp.131-136.

Sanità, H. (2016) 'Heritage, territory, identity, ennoblement of typical local products. L'Oro di Capri: a model of sustainable development', Procedia - Social and Behavioral Sciences, Vol. 223, pp.676-680.

Schmitt, E., Galli, F., Menozzi, D., Maye, D., Touzard, J-M., Marescotti, A., Six, J. and Brunori, G. (2017) 'Comparing the sustainability of local and global food products in Europe', Journal of Cleaner Production, Vol. 165, pp.346-359.

Sengel, T., Karagoz, A., Cetin, G., Dincer, F.I., Ertugral, S.M. and Balik, M. (2015) 'Tourists' approach to local food', Procedia - Social and Behavioral Sciences, Vol. 195, pp.429-437.

Sharma, A., Moon, J. and Strohbehn, C. (2014) 'Restaurant's decision to purchase local foods: influence of value chain activities', International Journal of Hospitality Management, Vol. 39, pp.130-143.

Shin, Y.H., Kim, H. and Severt, K. (2019) 'Consumer values and service quality perceptions of food truck experiences', International Journal of Hospitality Management, Vol. 79, No. 5, pp.11-20.

Sin, H.L. and Minca, C. (2014) 'Touring responsibility: the trouble with 'going local' in community-based tourism in Thailand', Geoforum, Vol. 51, pp.96-106.

Song, H., Livat, F. and Ye, S. (2019) 'Effects of terrorist attacks on tourist flows to France: is wine tourism a substitute for urban tourism?', Journal of Destination Marketing \& Management, Vol. 14, No. 1, p.100385.

Soontiens, W., Dayaram, K., Burgess, J. and Grimstad, S. (2018) 'Bittersweet? Urban proximity and wine tourism in the Swan Valley Region', Tourism Management Perspectives, Vol. 28, pp.105-112.

Stewart, J.X., Bramble, L. and Zirald, D. (2008) 'Key challenges in wine and culinary tourism with practical recommendations', International Journal of Contemporary Hospitality Management, Vol. 20, No. 3, pp.302-312.

Sung, Y-K., Su, C-S. and Chang, W-C. (2016) 'The quality and value of Hualien's Amis Harvest Festival', Annals of Tourism Research, Vol. 56, pp.128-163.

Szpilko, D. (2017) 'Tourism supply chain - overview of selected literature', Procedia Engineering, Vol. 182, pp.687-693.

Tama, H.A. and Voon, B.H. (2014) 'Components of customer emotional experience with halal food establishments’, Procedia - Social and Behavioral Sciences, Vol. 121, pp.272-280. 
Tanwar, M., Tanwar, B., Tanwar, R.S., Kumar, V. and Goyal, A. (2018) 'Himachali dham: food, culture, and heritage', Journal of Ethnic Foods, Vol. 5, No. 2, pp.99-104.

Taylor Jr., S., DiPietro, R.B. and So, K.K.F. (2018) 'Increasing experiential value and relationship quality: an investigation of pop-up dining experiences', International Journal of Hospitality Management, Vol. 74, pp.45-56.

Thach, L. and Olsen, J. (2015) 'Profiling the high frequency wine consumer by price segmentation in the US market', Wine Economics and Policy, Vol. 4, No. 1, pp.53-59.

Thanh, T.V. and Kirova, V. (2018) 'Wine tourism experience: a netnography study', Journal of Business Research, Vol. 83, No. 1, pp.30-37.

Thomas-Francois, K., Massow, M. and Joppe, M. (2017) 'Service-oriented, sustainable, local food value chain - a case study', Annals of Tourism Research, Vol. 65, pp.83-96.

Ting, H., Fam, K-S., Hwa, J.C.J., Richard, J.E. and Xing, N. (2019) 'Ethnic food consumption intention at the touring destination: the national and regional perspectives using multi-group analysis', Tourism Management, Vol. 71, pp.518-529.

Ting, H., Tan, S.R. and John, A.N. (2017) 'Consumption intention toward ethnic food: determinants of Dayak food choice by Malaysians', Journal of Ethnic Foods, Vol. 4, No. 1, pp.21-27.

Tsai, C-T. and Wang, Y-C. (2017) 'Experiential value in branding food tourism', Journal of Destination Marketing \& Management, Vol. 6, No. 1, pp.56-65.

Vajirakachorn, T. and Chongwatpol, J. (2017) 'Application of business intelligence in the tourism industry: a case study of a local food festival in Thailand', Tourism Management Perspectives, Vol. 23, pp.75-86.

Vargas-Sánchez, A. and López-Guzmán, T. (2018) 'Protection of culinary knowledge generation in Michelin-starred restaurants. The Spanish case', International Journal of Gastronomy and Food Science, Vol. 14, pp.27-34.

Vesci, M. and Botti, A. (2019) 'Festival quality, theory of planned behavior and revisiting intention: evidence from local and small Italian culinary festivals', Journal of Hospitality and Tourism Management, Vol. 38, pp.5-15.

Wang, L., Liu, J.M., Wang, L.E., Zhu, H. and Lin, J. (2018) 'Tourism resource assessment and spatial analysis of wine tourism development: a case study of the eastern foothills of China's Helan Mountains', Journal of Mountain Science, Vol. 15, No. 3 [online] https://doi.org/ 10.1007/s11629-016-4350-3.

Wijaya, S. (2019) 'Indonesian food culture mapping: a starter contribution to promote Indonesian culinary tourism', Journal of Ethnic Foods, Vol. 6, p.9 [online] https://doi.org/10.1186/ s42779-019-0009-3.

Williams, L.T., Germov, J., Fuller, S. and Freij, M. (2015) 'A taste of ethical consumption at a slow food festival', Appetite, Vol. 91, pp.321-328.

Wondirad, A., Kebete, Y. and Li, Y. (2021) 'Culinary tourism as a driver of regional economic development and socio-cultural revitalization: evidence from Amhara National Regional State, Ethiopia', Journal of Destination Marketing and Management, Vol. 19 [online] https://doi.org/ 10.1016/j.jdmm.2020.100482.

Wong, I.A., Liu, D., Li, N., Wu, S., Lu, L. and Law, R. (2019) 'Foodstagramming in the travel encounter', Tourism Management, Vol. 71, pp.99-115.

World Food Travel Association (2020) Food Travel Monitor.

World Health Organization (2015) International Travel and Health, WHO Press, Geneva.

Wu, H-C., Cheng, C-C., Ai, C-H. and Chen, G. (2019) 'Relationships between restaurant attachment, experiential relationship quality and experiential relationship intentions: the case of single friendly restaurants in Taiwan', Journal of Hospitality and Tourism Management, Vol. 40, pp.50-66.

Wu, K., Raab, C., Chang, W. and Krishen, A. (2016) 'Understanding Chinese tourists' food consumption in the United States', Journal of Business Research, Vol. 69, No. 10, pp.4706-4713. 
Wu, T-C., Xie, P.F. and Tsai, M-C. (2015) 'Perceptions of attractiveness for salt heritage tourism: a tourist perspective', Tourism Management, Vol. 51, pp.201-209.

Xiong, D.X. and Brownlee, I.A. (2018) 'Memories of traditional food culture in the kampong setting in Singapore', Journal of Ethnic Foods, Vol. 5, No. 2, pp.133-139.

Xu, S., Barbieri, C., Anderson, D., Leung, Y-F. and Rozier-Rich, S. (2016) 'Residents' perceptions of wine tourism development', Tourism Management, Vol. 55, pp.276-286.

Youn, H. and Kim, J-H. (2017) 'Effects of ingredients, names and stories about food origins on perceived authenticity and purchase intentions', International Journal of Hospitality Management, Vol. 63, pp.11-21.

Yousaf, S. and Xiucheng, F. (2018) 'Halal culinary and tourism marketing strategies on government websites: a preliminary analysis', Tourism Management, Vol. 68, pp.423-443.

Yu, C-E. and Sun, R. (2019) 'The role of Instagram in the UNESCO's creative city of gastronomy: a case study of Macau', Tourism Management, Vol. 75, No. 6, pp.257-268.

Zhang, H., Li, L., Yang, Y. and Zhang, J. (2018) 'Why do domestic tourists choose to consume local food? The differential and non-monotonic moderating effects of subjective knowledge', Journal of Destination Marketing \& Management, Vol. 10, pp.68-77.

Zhou, X., Tilburg, W.A.P., Mei, D., Wildschut, T. and Sedikides, C. (2019) 'Hungering for the past: nostalgic food labels increase purchase intentions and actual consumption', Appetite, Vol. 140, pp.151-158. 